Check for updates

Cite this: Chem. Sci., 2019, 10, 11054

๑ All publication charges for this article have been paid for by the Royal Society of Chemistry

Received 5th September 2019

Accepted 16th October 2019

DOI: $10.1039 / c 9 s c 04501 e$

rsc.li/chemical-science

\section{Controlled scrambling reactions to polyphosphanes via bond metathesis reactions $\uparrow$}

\author{
Robin Schoemaker, ${ }^{a}$ Kai Schwedtmann, ${ }^{a}$ Antonio Franconetti, (ID b \\ Antonio Frontera, (D) ${ }^{b}$ Felix Hennersdorf (iD ${ }^{a}$ and Jan J. Weigand (D)*a
}

Triphosphanes $\mathrm{R}_{2}{ }_{2} \mathrm{PP}(\mathrm{R}) \mathrm{PR}_{2}{ }_{2}(9 \mathrm{a}, \mathrm{c}: \mathrm{R}=\mathrm{Py} ; 9 \mathrm{~b} \mathrm{R}=\mathrm{BTz}), 1,3$-diphenyl-2-pyridyl-triphospholane 9d and pentaphospholanes $(R P)_{5}(13: R=P y ; 18: R=B T z)$ are obtained in high yield of up to $98 \%$ from the reaction of dipyrazolylphosphanes $\mathrm{RPpyr}_{2}(5: \mathrm{R}=\mathrm{Py} ; 6: \mathrm{R}=\mathrm{BTz} ; \mathrm{pyr}=1$,3-dimethylpyrazolyl) and the respective secondary phosphane $\left(\mathrm{R}_{2}^{\prime} \mathrm{PH}, \mathrm{R}^{\prime}=\mathrm{Cy}(9 \mathrm{a}, \mathrm{b}),{ }^{t} \mathrm{Bu}(9 \mathrm{c}) ; \mathrm{PhPH}\left(\mathrm{CH}_{2}\right)_{2} \mathrm{PHPh}(9 \mathrm{~d})\right)$. The formation of derivatives $9 a-d$ proceeds via a condensation reaction while the formation of 13 and 18 can only be explained by a selective scrambling reaction. We realized that the reaction outcome is strongly solvent dependent as outlined by the controlled scrambling reaction pathway towards pentaphospholane 13 . In our further investigations to apply these compounds as ligands we first confined ourselves to the coordination chemistry of triphosphane 9a with respect to coinage metal salts and discussed the observation of different syn- and anti-isomeric metal complexes based on NMR and X-ray analyses as well as quantum chemical calculations. Methylation reactions of 9a with MeOTf yield triphosphan-1-ium

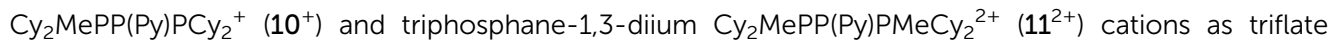
salts. Salt $11[\mathrm{OTf}]_{2}$ reacts with pentaphospholane 13 in an unprecedented chain growth reaction to give the tetraphosphane-1,4-diium triflate salt $\mathrm{Cy}_{2} \mathrm{MePP}(\mathrm{Py}) \mathrm{P}(\mathrm{Py}) \mathrm{PMeCy}_{2}{ }^{2+}\left(19[\mathrm{OTf}]_{2}\right)$ via a $\mathrm{P}-\mathrm{P} / \mathrm{P}-\mathrm{P}$ bond metathesis reaction. The latter salt is unstable in solution and rearranges via a rare [1,2]-migration of the $\mathrm{Cy}_{2} \mathrm{MeP}$-group followed by the elimination of the triphosph-2-en-1-ium cation $\left[\mathrm{Cy}_{2} \mathrm{MePPPMeCy}_{2}\right]^{+}$ $\left(20^{+}\right)$to yield a novel 1,4,2-diazaphospholium salt (21[OTf]).

\section{Introduction}

A wide range of polyphosphorus compounds, comprising diverse bonding motifs, have been synthesised in the last few decades. ${ }^{1,2}$ Many of the observed compounds are often found to be labile in solution and their rearrangement or decomposition reactions are discussed to proceed via intermolecular scrambling reactions. ${ }^{3}$ Even though there are early reports on controlling such scrambling reactions, ${ }^{4}$ the selective and high yielding synthesis of certain polyphosphanes is still difficult, hampering their subsequent chemistry. Besides classical approaches for the generation of P-P bonds such as salt metathesis reactions, ${ }^{2 a, b}$ dehalosilylation reactions ${ }^{2 c}$ or condensation reactions, ${ }^{2 d}$ our group focusses on the development of methodologies using tripyrazolylphosphane $\mathbf{1}$ or derivatives thereof (vide infra) as a $\mathrm{P}_{1}$-building unit for $\mathrm{P}-\mathrm{P}$ bond forming reactions via condensation or $\mathrm{P}-\mathrm{N} / \mathrm{P}-\mathrm{P}$ bond

${ }^{a}$ Faculty of Chemistry and Food Chemistry, TU Dresden, Chair of Inorganic Molecular Chemistry, 01062 Dresden, Germany.E-mail: jan.weigand@tu-dresden.de

${ }^{b}$ Department of Chemistry, Universitat de Illes Balears, 07122 Palma de Mallorca, Spain

$\dagger$ Electronic supplementary information (ESI) available. CCDC 1950469-1950486. For ESI and crystallographic data in CIF or other electronic format see DOI: $10.1039 / \mathrm{c} 9 \mathrm{sc} 04501 \mathrm{e}$ metathesis reactions (Scheme 1). ${ }^{5,6}$ In this regard, the reaction of $\mathbf{1}$ with $\mathrm{Cy}_{2} \mathrm{PH}$ to give triphosphane $\mathbf{2}$ or iso-tetraphosphane 3 depending on the applied stoichiometry has been reported. ${ }^{5}$ The reaction of 1 with 1,2-bis(phenylphosphanyl)ethane yields hexaphosphane 4 in a sequence of condensation and $\mathrm{P}-\mathrm{N} / \mathrm{P}-\mathrm{P}$ bond metathesis reactions, showing an example of a controlled scrambling reaction. ${ }^{6}$ In our effort to further control these metathesis reactions and driven by our general interest in azole-

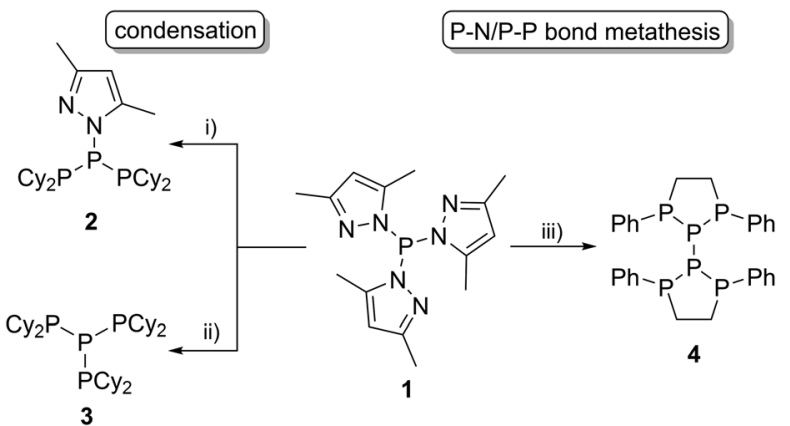

Scheme 1 Application of tripyrazolylphosphane 1 in $\mathrm{P}-\mathrm{P}$ bond formation reactions; (i) $2 \mathrm{Cy}_{2} \mathrm{PH},-2 \mathrm{pyrH}, \mathrm{CH}_{3} \mathrm{CN}$; (ii) $3 \mathrm{Cy}_{2} \mathrm{PH},-3$ pyrH, and $\mathrm{CH}_{3} \mathrm{CN}$; (iii) $5 \mathrm{PhPH}\left(\mathrm{CH}_{2}\right)_{2} \mathrm{PHPh}, 4 \mathrm{Ppyr}_{3},-\mathrm{PhP}(\mathrm{pyr})\left(\mathrm{CH}_{2}\right)_{2^{-}}$ $\mathrm{P}(\mathrm{pyr}) \mathrm{Ph},-10 \mathrm{pyrH}, \mathrm{CH}_{3} \mathrm{CN}$. 
and azine-substituted phosphanes, we explored the synthesis of phosphanes with a pyridyl- or benzothiazolyl-substituent bound to phosphorus via the carbon atom. This limits the number of $\mathrm{P}-\mathrm{N}$ bound pyrazolyl-substituents and therefore the possible reaction pathways by $\mathrm{P}-\mathrm{N} / \mathrm{P}-\mathrm{P}$ bond metathesis. For a better overview and in thought of a systematic approach we organised our general types of phosphanes with respect to their number of $\mathrm{P}-\mathrm{N}$ bound substituents as type I to type IV (Scheme 2). In type I phosphanes all three substituents are bound via $\mathrm{P}-\mathrm{N}$ bonds whereas a type II phosphane is defined by two $\mathrm{P}-\mathrm{N}$ bonds and one $\mathrm{P}-\mathrm{C}$ bond. This order is maintained in type III phosphanes with one $\mathrm{P}-\mathrm{N}$ and two $\mathrm{P}-\mathrm{C}$ bonds and is finalised in type IV phosphanes featuring only $\mathrm{P}-\mathrm{C}$ bonds. Importantly, all substituents at the phosphorus atom have an additional $\mathrm{sp}^{2}$ hybridised donor atom such as nitrogen, being essential as a further reaction or coordination site and for the possible formation of resonance stabilised reaction intermediates. In this contribution, we report the synthesis of the hitherto unknown type II phosphanes carrying either a pyridyl- or benzothiazolyl-substituent and their use for the generation of triphosphanes, a triphospholane and pentaphospholanes and selected one triphosphane to explore its coordination chemistry with respect to coinage metal salts.

\section{Results and discussion}

The targeted type II phosphanes are synthesised by the reaction of the dichlorophosphanes $\mathrm{RPCl}_{2}(\mathrm{R}=\mathrm{Py}(5) ; \mathrm{R}=\mathrm{BTz}(\mathbf{6}))^{7,8}$ with two equivalents of 3,5-dimethyl-1-(trimethylsilyl)pyrazole (Scheme 3). ${ }^{9}$ The released chloro(trimethyl)silane can be removed under reduced pressure after 16 hours and no further purification is necessary. Both phosphanes 7 and $\mathbf{8}$ are conveniently prepared on a multi gram scale in excellent yields $(97 \%$ (7); 96\% (8)). The ${ }^{31} \mathrm{P}$ NMR spectra of the dipyrazolylphosphanes show a singlet resonance in each case $(7: \delta(\mathrm{P})=44.8 \mathrm{ppm} ; 8: \delta(\mathrm{P})$ $=38.0 \mathrm{ppm})$ being significantly shifted to a higher field compared to the corresponding dichlorophosphanes $(5: \delta(\mathrm{P})=$ $138.7 \mathrm{ppm}$; 6: $\delta(\mathrm{P})=132.0 \mathrm{ppm})$. Suitable crystals for X-ray analysis of phosphanes 7 and $\mathbf{8}$ are obtained by slow vapour diffusion of $n$-pentane into a saturated $\mathrm{CH}_{2} \mathrm{Cl}_{2}$ solution of 7 and
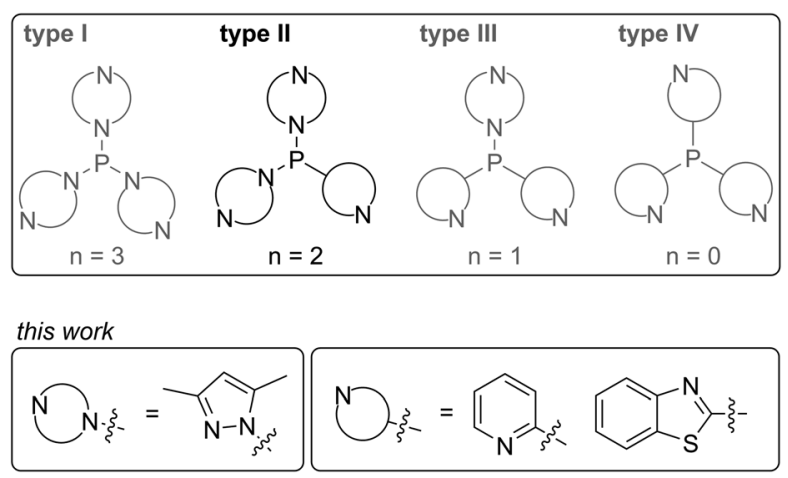

Scheme 2 Classification of $\mathrm{N}$-heterocyclic substituted phosphanes into type I to type IV phosphanes ( $n$ is the number of $\mathrm{P}-\mathrm{N}$ bonds) with an emphasis on the type II phosphanes presented in this contribution.

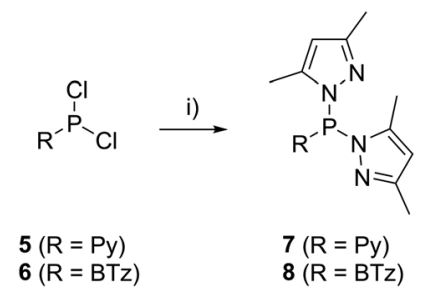

Scheme 3 Synthesis of dipyrazolylphosphanes 7 and 8 ; $R=P y$; (i) 2 eq. pyrSiMe 3 , neat, $-2 \mathrm{Me}_{3} \mathrm{SiCl}$; $\mathrm{R}=\mathrm{BTz}$; (i) 2 eq. pyrSiMe $, \mathrm{Et}_{2} \mathrm{O},-2$ $\mathrm{Me}_{3} \mathrm{SiCl}$.

8. Their molecular structures are depicted in Fig. 1. The $\mathrm{P}-\mathrm{C}$ bond lengths (7: P1-C1 1.827(1) A; 8: P1-C1 1.828(2) ̊) are in the expected range of a $\mathrm{P}-\mathrm{C}$ single bond $(1.83 \AA),{ }^{10}$ involving a tri-coordinate phosphorus atom. For both phosphanes the P-N bond lengths (7: P1-N4 1.721(1) Å, P1-N2 1.724(1) Aं; 8 P1$\mathrm{N} 2 / \mathrm{N} 2$ ' $1.719(1) \AA)$ are in accordance with those reported for tri(1H-pyrazol-1-yl)phosphane $(1.714(4) \AA) .{ }^{11}$ In continuation, we carried out the reaction of dipyrazolylphosphanes 7 and $\mathbf{8}$ with secondary phosphanes $\mathrm{R}_{2}^{\prime} \mathrm{PH}\left(\mathrm{R}^{\prime}=\mathrm{Cy}, t \mathrm{Bu}\right.$ or $\mathrm{R}_{2}^{\prime} \mathrm{PH}=$ $\left.\mathrm{PhP}(\mathrm{H}) \mathrm{C}_{2} \mathrm{H}_{4} \mathrm{P}(\mathrm{H}) \mathrm{Ph}\right)$ to give triphosphanes 9a-c and triphospholane 9d with concomitant release of two equivalents of 3,5dimethylpyrazole (Scheme 4). Compounds 9a-d readily precipitate from the reaction mixture and are isolated by filtration. Subsequent washing with $\mathrm{CH}_{3} \mathrm{CN}$ and drying in vacuo give 9ad as colourless solids in good to excellent yield (96\% (9a); 93\% (9b); 77\% (9c); 69\% (9d)). The ${ }^{31} \mathrm{P}$ NMR spectra of all compounds show $\mathrm{AX}_{2}$ spin systems which are characteristic of triphosphanes and 1,2,3-triphospholanes (Fig. 2). The NMR spectroscopic parameters are listed in Table 1. Single crystals for X-ray analysis are obtained by slow vapour diffusion of $n$ pentane into saturated $\mathrm{CH}_{2} \mathrm{Cl}_{2}$ solutions of $9 \mathbf{a}-\mathbf{d}$. The molecular structures of 9a-d are depicted in Fig. 3. Their structural parameters compare very well with those of similar triphosphanes ${ }^{\mathbf{1 2}}$ and are thus not discussed in detail. Only the bond angle of the $\mathrm{P}-\mathrm{P}-\mathrm{P}$ moiety in compound $9 \mathrm{c}$ is approximately $10^{\circ}$ wider which can be explained by the sterically demanding tertbutyl substituents. In recent years numerous examples of the coordination chemistry of anionic ${ }^{\mathbf{1 3}}$ and zwitterionic ${ }^{\mathbf{1 4}}$ oligophosphorus compounds towards transition metals have been
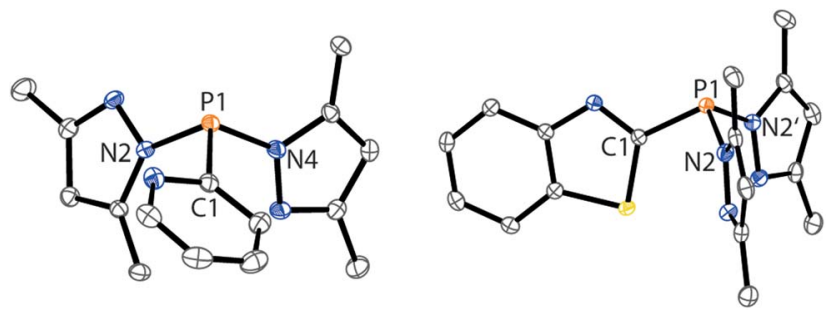

Fig. 1 Molecular structures of 7 (left) and 8 (right) (hydrogen atoms are omitted for clarity and thermal ellipsoids are displayed at $50 \%$ probability). Selected bond lengths ( $\AA$ ) and angles $\left({ }^{\circ}\right)$ : (7) P1-C1 1.827(1), P1N4 1.721(1), P1-N2 1.724(1), C1-P1-N4 101.28(5), N4-P1-N2 103.26(5), N2-P1-C1 100.18(5); (8) P1-C1 1.828(2), P1-N2 1.719(1), C1-P1-N2 101.26(5), N2-P1-N2' 103.84(7). 


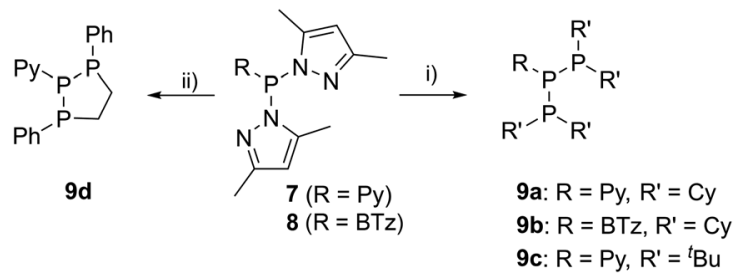

Scheme 4 Synthesis of triphosphanes $9 \mathrm{a}-\mathrm{c}$ : (i) +2 eq. $\mathrm{R}_{2}{ }_{2} \mathrm{PH}, \mathrm{CH}_{3} \mathrm{CN}$, $-2 \mathrm{pyrH}$; and triphospholane 9d: (ii) 1 eq. $\mathrm{PhPH}\left(\mathrm{CH}_{2}\right)_{2} \mathrm{PHPh}, \mathrm{CH}_{3} \mathrm{CN}$, $-2 \mathrm{pyrH}$.

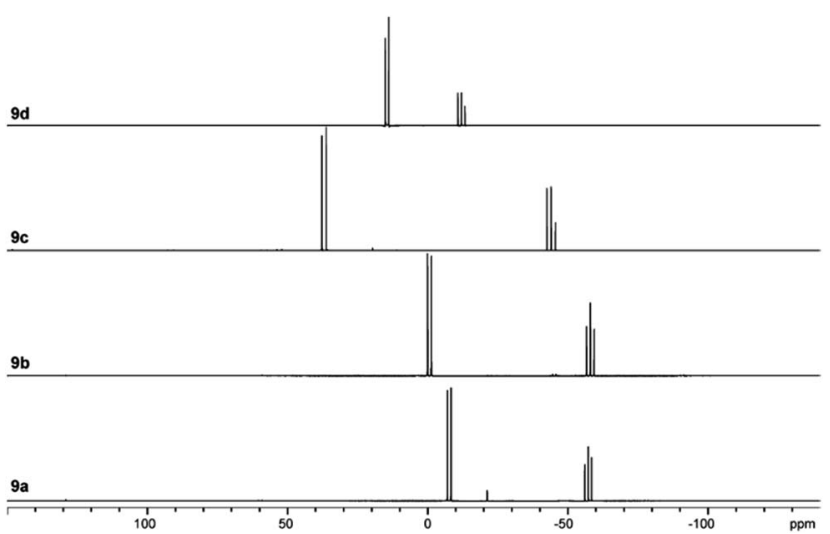

Fig. $2{ }^{31}$ P NMR spectra of compounds $9 a-d$.

Table $1{ }^{31}$ P NMR parameters of compounds $9 a-d$

\begin{tabular}{llll}
\hline Compound & \multicolumn{2}{c}{ Chemical shifts $(\mathrm{ppm})$} & ${ }^{1} \mathrm{PP}(\mathrm{Hz})$ \\
\hline 9a & -57.3 & -7.7 & -251 \\
9b & -58.1 & -0.7 & -268 \\
9c & -44.1 & 37.0 & -307 \\
9d & -12.1 & 14.5 & -260 \\
\hline
\end{tabular}

reported. Also, few examples of neutral triphosphanes coordinated to transition metals are known, however, the triphosphane moiety was assembled while coordinated to at least one metal centre. ${ }^{15}$ Starting from stable triphosphanes only two complexes coordinating to metal carbonyls have been structurally characterised (Scheme 5, top), ${ }^{\mathbf{5} 16}$ while another example is described in solution. ${ }^{17}$ In complex I, the triphosphane ligand chelates the $\mathrm{W}(\mathrm{CO})_{4}$ moiety while in complex II the coordination of the $\mathrm{Fe}(\mathrm{CO})_{4}$ moiety proceeds only via the free electron pair of one of the dicylcohexylphosphanyl groups. Featuring an additional nitrogen based donor site we envisioned the formation of multi-dentate coinage metal complexes using triphosphane 9a, exemplarily. This yielded the first triphosphane coordination complexes of $\mathrm{Cu}(\mathrm{I}), \mathrm{Ag}(\mathrm{I})$ and $\mathrm{Au}(\mathrm{I})$ (Scheme 5). Reacting 9a with an equimolar amount of Ag[OTf] in fluorobenzene at room temperature leads to the formation of a colourless precipitate which is isolated by filtration to yield the dinuclear complex $\left[(\mathbf{9 a *} \mathrm{Ag})_{2}\right][\mathrm{OTf}]_{2}$ in essentially quantitative yield. The corresponding reaction of 9 a with $\left[(\mathrm{MeCN})_{4} \mathrm{Cu}\right]$ [OTf] in $\mathrm{CH}_{2} \mathrm{Cl}_{2}$ gives colourless plates upon slow vapour diffusion of $n$-pentane at $-30{ }^{\circ} \mathrm{C}$ which can be isolated as $\left[(\mathbf{9 a} * \mathrm{Cu})_{2}\right][\mathrm{OTf}]_{2}$ up to a yield of $94 \%$. Further transmetallation reaction of $\left[\left(9 \mathbf{a}^{*} \mathrm{Ag}\right)_{2}\right][\mathrm{OTf}]_{2}$ with (tht)AuCl in $\mathrm{MeCN}$ gives $\left[\left(9 a^{*} \mathrm{Au}\right)_{2}\right][\mathrm{OTf}]_{2}$ in $64 \%$ yield by the concomitant precipitation of AgCl. Slow diffusion of $n$-pentane into a $\mathrm{CH}_{2} \mathrm{Cl}_{2}$ solution of 9a and $\left[(\mathrm{MeCN})_{4} \mathrm{Cu}\right][\mathrm{OTf}]$ in a $2: 1$ ratio gives crystalline $\left[(9 \mathbf{9 a})_{2}{ }^{*} \mathrm{Cu}\right]$ [OTf] in $93 \%$ yield. Formation of $\left(9 a^{*} \mathrm{CuBr}\right)_{2}$ is achieved by slow diffusion of $n$-pentane into a THF solution of equimolar amounts of 9a and (tht)CuBr. The molecular structures of the aforementioned coinage metal complexes are shown in Fig. 4 and the structural parameters are summarised in Table 2. Different from the known coordination motifs for I and II, the molecular structures of $\left[(\mathbf{9 a} * \mathrm{Cu})_{2}\right][\mathrm{OTf}]_{2},\left[(\mathbf{9 a * A g})_{2}\right][\mathrm{OTf}]_{2}$ and $\left[(\mathbf{9 a} * \mathrm{Au})_{2}\right][\mathrm{OTf}]_{2}$ reveal dinuclear metal complexes featuring two triphosphane ligands. In addition to the terminal coordinating phosphorus atoms, the nitrogen atoms of the pyridylsubstituents are involved in the coordination resulting in an approximately tetrahedral coordination environment of the respective metal centre. While the molecular structures of the dinuclear complexes $\left[(\mathbf{9 a} * \mathrm{Cu})_{2}\right][\mathrm{OTf}]_{2}$ and $\left[(\mathbf{9 a * A g})_{2}\right][\mathrm{OTf}]_{2}$ reveal an anti-arrangement with inversion symmetry, the gold complex $\left[(\mathbf{9 a} * \mathrm{Au})_{2}\right][\mathrm{OTf}]_{2}$ crystallises as a centro-symmetrical $s y n$-isomer. The inversion process within the complexes has
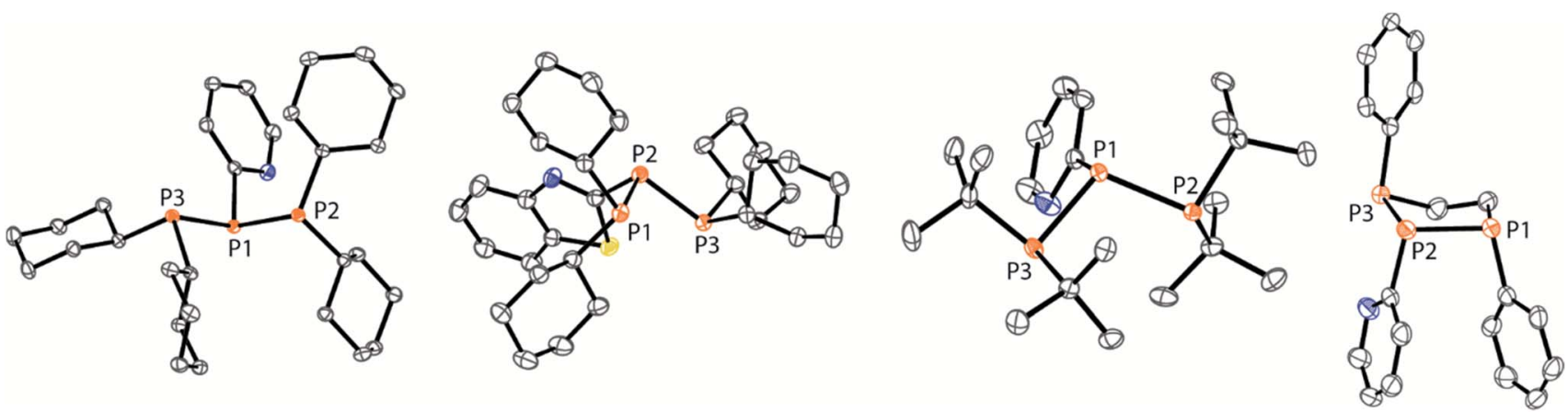

Fig. 3 Molecular structures of triphosphanes $9 a-c$ and triphospholane $9 \mathrm{~d}$ (hydrogen atoms are omitted for clarity and thermal ellipsoids are displayed at 50\% probability). Selected bond lengths (Å) and angles ( ${ }^{\circ}$ ) (9a): P1-P2 2.2301(3), P1-P3 2.2371(3), P3-P1-P2 97.38(1) (9b); P1-P2 2.2377(5), P2-P3 2.2234(5), P1-P2-P3 98.11(2) (9c); P1-P2 2.2181(3), P1-P3 2.2485(3), P2-P1-P3 107.64(1) (9d); P1-P2 2.270(2), P2-P3 2.197(2), P1-P2-P3 97.16(6). 
Known triphosphanes coordinating to metal carbonyls

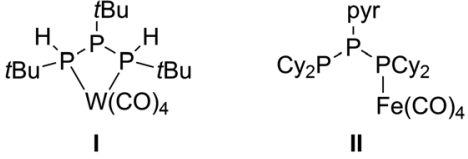
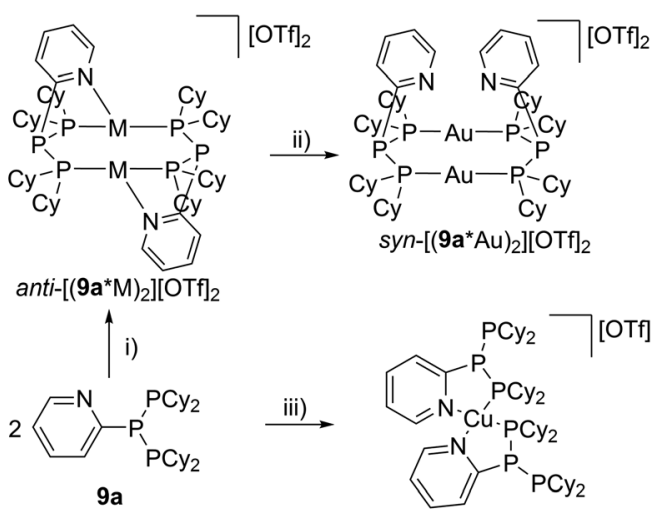

$\left[(9 \mathrm{a})_{2}{ }^{*} \mathrm{Cu}\right][\mathrm{OTf}]$

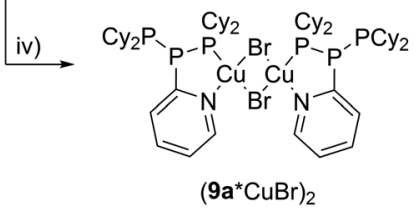

Scheme 5 Known transition metal complexes featuring a neutral triphosphane ligand (top); synthesis of coinage metal coordination complexes starting from triphosphane 9a (bottom); (i) 2 eq. Ag[OTf], $\operatorname{PhF}(\mathrm{M}=\mathrm{Ag}) ; 2$ eq. [(MeCN) $\left.{ }_{4} \mathrm{Cu}\right][\mathrm{OTf}], \mathrm{CH}_{2} \mathrm{Cl}_{2},-8 \mathrm{MeCN}(\mathrm{M}=\mathrm{Cu})$; (ii) 2 eq. (tht) $\mathrm{AuCl}, \mathrm{MeCN},-2$ tht, $-2 \mathrm{AgCl}$; (iii) 1 eq. [(MeCN) $\left.{ }_{4} \mathrm{Cu}\right][\mathrm{OTf}$, $\mathrm{CH}_{2} \mathrm{Cl}_{2},-4 \mathrm{MeCN}$; (iv) 2 eq. (tht) $\mathrm{CuBr}, \mathrm{THF},-2$ tht. been investigated by variable temperature NMR experiments and theoretical calculations (vide infra). The difference in the arrangement in the solid state causes a widening of the $\mathrm{P}-\mathrm{M}-\mathrm{P}$ angles in the copper complex $\left[\left(\mathbf{9 a}{ }^{*} \mathrm{Cu}\right)_{2}\right][\mathrm{OTf}]_{2} \quad\left(\mathrm{P} 3^{\prime}-\mathrm{Cu} 1-\mathrm{P} 1\right.$ $\left.136.52(2)^{\circ}\right)$ compared to the silver complex $\left[\left(\mathbf{9} \mathbf{a}^{*} \mathrm{Ag}\right)_{2}\right][\mathrm{OTf}]_{2}$ (P1-Ag1-P3' $\left.143.96(3)^{\circ}\right)$ to an almost linear geometry around the gold atoms in $\left[\left(9 \mathbf{a}^{*} \mathrm{Au}\right)_{2}\right][\mathrm{OTf}]_{2}\left(\mathrm{P} 1-\mathrm{Au} 1-\mathrm{P} 3^{\prime} 171.52(3)^{\circ}\right)$. The distances between the silver atoms in $\left[\left(\mathbf{9} \mathbf{a}^{*} \mathrm{Ag}\right)_{2}\right][\mathrm{OTf}]_{2}$ and the gold atoms in $\left[\left(\mathbf{9} \mathbf{a}^{*} \mathrm{Au}\right)_{2}\right][\mathrm{OTf}]_{2}$ indicate the presence of argentophilic and aurophilic interactions, respectively. ${ }^{18}$ As the distance between the copper atoms in $\left[(\mathbf{9 a} \cdot \mathrm{Cu})_{2}\right][\mathrm{OTf}]_{2}$ is slightly larger than the sum of the van der Waals radii of two copper atoms $(2.80 \AA),{ }^{19}$ significant van der Waals interactions can be excluded. The observed $\mathbf{P}-\mathbf{M}$ bond lengths in $\left[\left(9 \mathbf{a}^{*} \mathbf{M}\right)_{2}\right]$ $[\mathrm{OTf}]_{2}$ as well as in $\left[(\mathbf{9 a})_{2} * \mathrm{Cu}\right][\mathrm{OTf}]$ and $(\mathbf{9 a} * \mathrm{CuBr})_{2}$ are in good agreement with bond lengths reported for the structurally similar $\left[\mathrm{M}_{2}(\mathrm{dcpm})_{2}\right]^{2+}$ cations $(\mathrm{M}=\mathrm{Cu}(\mathrm{I}), \mathrm{Ag}(\mathrm{I})$ or $\mathrm{Au}(\mathrm{I})$; depm $=$ bis(dicylcohexylphosphanyl)methane). ${ }^{20}$ For $\left(9 a^{*} \mathrm{CuBr}\right)_{2}$ the formation of the typical $\mathrm{Cu}_{2} \mathrm{X}_{2}(\mathrm{X}=$ halogen $)$ geometry is found, only marginally differing from the typical planar arrangement reported for many $\mathrm{Cu}_{2} \mathrm{X}_{2}$-type structures. ${ }^{21}$ Compared to free ligand 9a, the $\mathrm{P}-\mathrm{P}$ bond lengths and the $\mathrm{P}-\mathrm{P}-\mathrm{P}$ angles in the coinage metal complexes are only marginally altered. The room temperature NMR spectra of the dinuclear complexes $\left[\left(9 \mathbf{a}^{*} \mathrm{Au}\right)_{2}\right]$ $[\mathrm{OTf}]_{2}$ and $\left[(\mathbf{9 a * A g})_{2}\right][\mathrm{OTf}]_{2}$ show broadened resonances due to dynamic processes in solution. ${ }^{22}$ The low temperature ${ }^{31} \mathrm{P}$ NMR spectrum of $\left[\left(9 \mathbf{a}^{*} \mathrm{Au}\right)_{2}\right][\mathrm{OTf}]_{2}$ shows two separate $\mathrm{AA}^{\prime} \mathrm{XX}^{\prime} \mathrm{X}^{\prime \prime} \mathrm{X}^{\prime \prime \prime}$ spin systems at $\delta\left(\mathrm{P}_{\mathrm{A}}\right)=-34.2 \mathrm{ppm}, \delta\left(\mathrm{P}_{\mathrm{X}}\right)=52.6 \mathrm{ppm}$ and $\delta\left(\mathrm{P}_{\mathrm{A}}\right)$ $=-37.8 \mathrm{ppm}, \delta\left(\mathrm{P}_{\mathrm{X}}\right)=50.3 \mathrm{ppm}$ corresponding to the respective syn- and anti-isomers (Fig. 5). Details of the coupling constants are included in the ESI. $\dagger$ For $\left[(\mathbf{9 a * A g})_{2}\right][\mathrm{OTf}]_{2}$ two isomers with two separate $\mathrm{AA}^{\prime} \mathrm{XX}^{\prime} \mathrm{X}^{\prime \prime} \mathrm{X}^{\prime \prime \prime}$ spin systems at $\delta\left(\mathrm{P}_{\mathrm{A}}\right)=-48.5 \mathrm{ppm}$, $\delta\left(\mathrm{P}_{\mathrm{X}}\right)=36.1 \mathrm{ppm}$ and $\delta\left(\mathrm{P}_{\mathrm{A}}\right)=-51.5 \mathrm{ppm}, \delta\left(\mathrm{P}_{\mathrm{X}}\right)=36.1 \mathrm{ppm}$ are
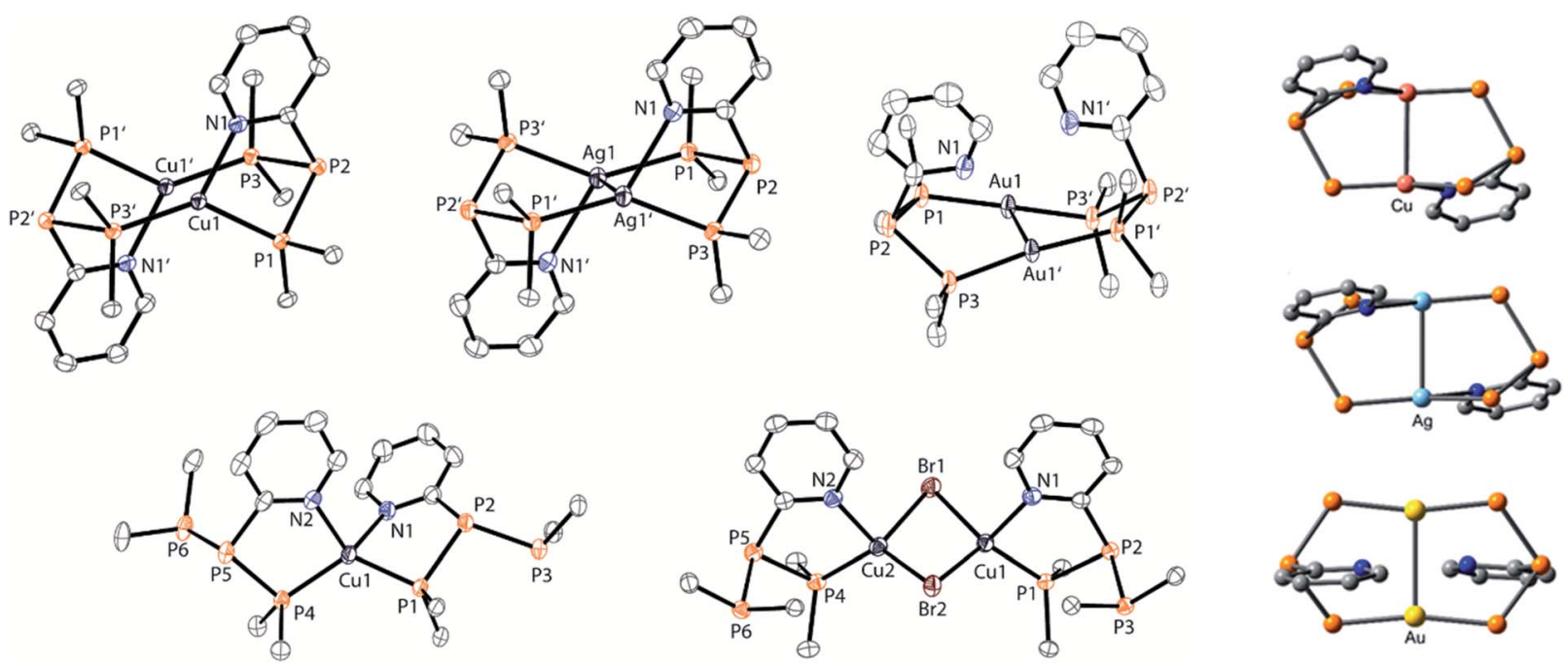

Fig. 4 Molecular structures of the coinage metal complexes $\left[(9 a * \mathrm{Cu})_{2}\right][\mathrm{OTf}]_{2},\left[(9 a * \mathrm{Ag})_{2}\right][\mathrm{OTf}]_{2},\left[(9 a * \mathrm{Au})_{2}\right][\mathrm{OTf}]_{2},\left[(9 a)_{2} * \mathrm{Cu}\right][\mathrm{OTf}]$ and $(9 a * \mathrm{CuBr})_{2}$ (hydrogen atoms, anions and solvate molecules are omitted for clarity, cyclohexyl groups are represented only by their phosphorus bound carbon atoms, and thermal ellipsoids are displayed at 50\% probability; left). Selected geometrical parameters are given in Table 2; Optimised geometries of $\left[(9 a * M)_{2}\right][O T f]_{2}$ using the BP86-D3/def2-TZVP functional, showing the different coordination arrangement of the pyridyl-moieties towards the metal atoms ( $\mathrm{M}=\mathrm{Cu}, \mathrm{Ag}$, and $\mathrm{Au}$; right). 
Table 2 Selected geometrical parameters of crystallographically characterised coinage metal complexes $\left[(9 a * \mathrm{Cu})_{2}\right][\mathrm{OTf}]_{2},\left[(9 a * \mathrm{Ag})_{2}\right][\mathrm{OTf}]_{2}$, $\left[(9 a * A u)_{2}\right][O T f]_{2},\left[(9 a)_{2} * \mathrm{Cu}\right][\mathrm{OTf}]$ and $(9 a * \mathrm{CuBr})_{2}$

\begin{tabular}{|c|c|c|c|c|c|}
\hline & {$\left[\left(\mathbf{9 a}{ }^{*} \mathrm{Cu}\right)_{2}\right][\mathrm{OTf}]_{2}$} & {$\left[(\mathbf{9 a} * \mathrm{Ag})_{2}\right][\mathrm{OTf}]_{2}$} & {$\left[(\mathbf{9 a} * \mathrm{Au})_{2}\right][\mathrm{OTf}]_{2}$} & {$\left[(\mathbf{9 a})_{2}{ }^{*} \mathrm{Cu}\right][\mathrm{OTf}]^{a}$} & $\left(9 a^{*} \mathrm{CuBr}\right)_{2}{ }^{a}$ \\
\hline M1-M1 ${ }^{\prime}$ in $\AA$ & $2.8225(5)$ & $2.9013(4)$ & $2.880(3)$ & - & 2.942 \\
\hline M1-P1 in $\AA$ & $2.2755(4)$ & $2.3818(8)$ & $2.3033(8)$ & 2.243 & 2.191 \\
\hline $\mathrm{M}-\mathrm{N}$ in $\AA$ & $2.048(1)$ & $2.404(3)$ & $2.948(3)$ & 2.106 & 2.116 \\
\hline $\mathrm{P}-\mathrm{P}^{a}$ in $\AA$ & 2.225 & 2.224 & 2.226 & 2.212 & 2.214 \\
\hline P1-M1-P3 in ${ }^{\circ}$ & $136.52(2)$ & $143.96(3)$ & $171.52(3)$ & - & - \\
\hline
\end{tabular}

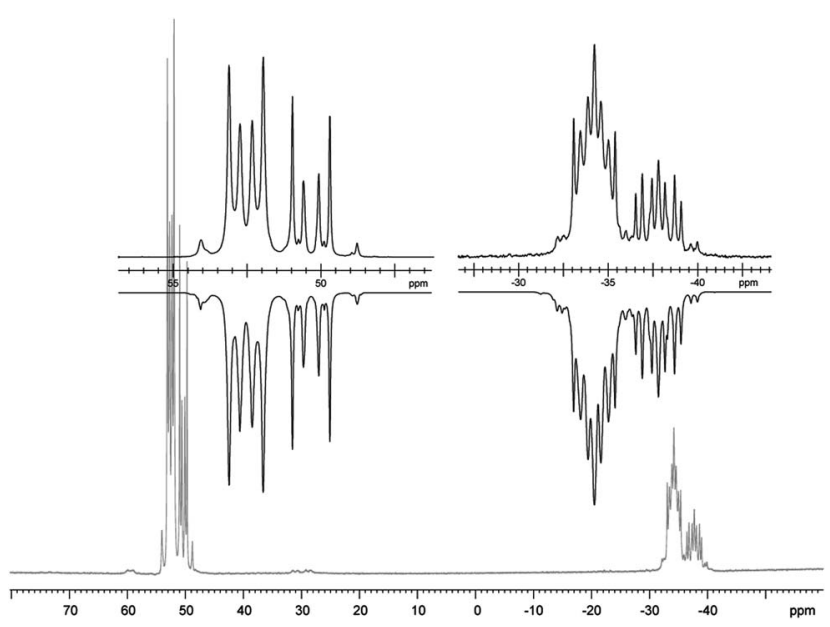

Fig. $5{ }^{31} \mathrm{P}$ NMR spectrum of $\left[(9 a * A u)_{2}\right][O T f]_{2}\left(\mathrm{CD}_{2} \mathrm{Cl}_{2}, 243 \mathrm{~K}\right.$, insets show the two $A A^{\prime} X X^{\prime} X^{\prime \prime} X^{\prime \prime \prime}$ spin systems of the experimental (upwards) and fitted spectra (downwards)).

also observed. However, further line splitting can be observed as a result of the complexation with the $\mathrm{Ag}^{107} / \mathrm{Ag}^{109}$ nuclei, which made us refrain from iteratively fitting the corresponding ${ }^{31} \mathrm{P}$ NMR spectrum. The ${ }^{31} \mathrm{P}$ NMR spectrum of the dinuclear copper complex $\left[\left(\mathbf{9 a} \mathbf{a}^{*} \mathrm{Cu}\right)_{2}\right][\mathrm{OTf}]_{2}$ shows only the resonances of one $\mathrm{AA}^{\prime} \mathrm{XX}^{\prime} \mathrm{X}^{\prime \prime} \mathrm{X}^{\prime \prime \prime}$ spin system at $\delta\left(\mathrm{P}_{\mathrm{A}}\right)=-39.1 \mathrm{ppm}$ and $\delta\left(\mathrm{P}_{\mathrm{X}}\right)=$ $15.4 \mathrm{ppm}$. An additional broadened $\mathrm{AX}_{2}$ spin system $\left(\delta\left(\mathrm{P}_{\mathrm{A}}\right)=\right.$ $-37.5 \mathrm{ppm}$ and $\left.\delta\left(\mathrm{P}_{\mathrm{X}}\right)=15.3 \mathrm{ppm}\left({ }^{1} J\left(\mathrm{P}_{\mathrm{A}} \mathrm{P}_{\mathrm{X}}\right)=-168 \mathrm{~Hz}\right)\right)$ gives rise to the formation of a monomeric species in solution which was not further investigated. A comparable $\mathrm{AX}_{2}$ spin system is observed for $\left[(9 \mathbf{9 a})_{2} * \mathrm{Cu}\right][\mathrm{OTf}]\left(\delta\left(\mathrm{P}_{\mathrm{A}}\right)=-44.8 \mathrm{ppm}\right.$ and $\delta\left(\mathrm{P}_{\mathrm{X}}\right)=$ $\left.-8.9 \mathrm{ppm}\left({ }^{1} J\left(\mathrm{P}_{\mathrm{A}} \mathrm{P}_{\mathrm{X}}\right)=-275 \mathrm{~Hz}\right)\right)$ as well as for $\left(9 \mathbf{a}^{*} \mathrm{CuBr}\right)_{2}\left(\delta\left(\mathrm{P}_{\mathrm{A}}\right)\right.$ $=-46.6 \mathrm{ppm}$ and $\left.\delta\left(\mathrm{P}_{\mathrm{X}}\right)=-6.2 \mathrm{ppm}\left({ }^{1} J\left(\mathrm{P}_{\mathrm{A}} \mathrm{P}_{\mathrm{X}}\right)=-253 \mathrm{~Hz}\right)\right)$. For both mononuclear copper complexes the resonances in the ${ }^{31} \mathrm{P}$ NMR spectrum are noticeably broadened due to the fast quadrupole relaxation of the ${ }^{63} \mathrm{Cu}$ nucleus. ${ }^{22,23}$ Theoretical calculations performed at the BP86-D3/def2-TZVP level of theory support the isomerisation in the dinuclear metal complexes $\left[\left(\mathbf{9} \mathbf{a}^{*} \mathrm{M}\right)_{2}\right]^{2+}$. For $\left[\left(\mathbf{9 a} \mathbf{a}^{*} \mathrm{Cu}\right)_{2}\right]^{2+}$ we found a relative energy difference between the syn- and the anti-isomer of $5.0 \mathrm{kcal} \mathrm{mol}^{-1}$ which explains that only one isomer is observed in the ${ }^{31} \mathrm{P}$ NMR spectrum. While the two isomers of $\left[\left(9 \mathbf{a}^{*} \mathrm{Ag}\right)_{2}\right]^{2+}$ are isoenergetic with a difference of $0.1 \mathrm{kcal} \mathrm{mol}^{-1}$, the $s y n$-isomer of $\left[\left(9 \mathbf{a}^{*} \mathrm{Au}\right)_{2}\right]^{2+}$ is favored by $1.7 \mathrm{kcal} \mathrm{mol}^{-1}$ compared to its antiisomer. The optimised geometries also show the different coordination behaviour of the pyridyl-moieties in the three metal complexes $\left[\left(\mathbf{9} \mathbf{a}^{*} \mathbf{M}\right)_{2}\right]^{2+}$. While the free electron pair of the pyridyl nitrogen atom is pointing towards the metal centre in $\left[(\mathbf{9 a} * \mathrm{Cu})_{2}\right]^{2+}$ and $\left[(\mathbf{9 a} * \mathrm{Ag})_{2}\right]^{2+}$ it is pointing towards the middle of the $\mathrm{Au}-\mathrm{Au}$ bond in $\left[(\mathbf{9 a * A u})_{2}\right]^{2+}$ (Fig. 4, right). Our calculations furthermore indicate that the isomerisation is not driven by rotation but proceeds via dissociation of the $\mathrm{M}(\mathrm{I})-\mathrm{N}$ coordination bond or pseudo-coordination in the case of $\left[\left(9 \mathbf{a}^{*} \mathrm{Au}\right)_{2}\right]^{2+}$ and subsequent association of the ligand on the opposite side (Fig. 6). This interconversion is the highest in energy for $\left[\left(9 \mathbf{a}^{*} \mathrm{Cu}\right)_{2}\right]^{2+}\left(14.7 \mathrm{kcal} \mathrm{mol}^{-1}\right)$, followed by $\left[\left(9 \mathbf{a}^{*} \mathrm{Ag}\right)_{2}\right]^{2+}$ $\left(13.2 \mathrm{kcal} \mathrm{mol}^{-1}\right)$ and finally $\left[\left(9 \mathrm{a}^{*} \mathrm{Au}\right)_{2}\right]^{2+}\left(9.6 \mathrm{kcal} \mathrm{mol}^{-1}\right) .{ }^{23}$

Further reactivity studies on triphosphane 9a revealed that this compound readily rearranges in solution by means of a $\mathrm{P}-$ $\mathrm{P} / \mathrm{P}-\mathrm{P}$ bond metathesis reaction. After $24 \mathrm{~h}$ the $\mathrm{CH}_{2} \mathrm{Cl}_{2}$ solution of 9a shows an additional singlet resonance at $\delta(\mathrm{P})=21.0 \mathrm{ppm}$ which we assign to tetracyclohexyldiphosphane $(\mathbf{1 2})^{\mathbf{2 4}}$ and an $\mathrm{AA}^{\prime} \mathrm{BB}^{\prime} \mathrm{C}$ spin system at $\delta(\mathrm{P})=14.0-25.2 \mathrm{ppm}$ being characteristic of pentaphospholanes of type $(\mathrm{RP})_{5} \cdot{ }^{24,25}$ As this scrambling reaction is in a state of equilibrium the isolation of $\mathbf{1 3}$ is hampered. However, the reaction of pure 13 with $\mathrm{Cy}_{4} \mathrm{P}_{2}$ yielding 9a illustrates that pentaphospholane 13 might be used as a PyP-synthon as it inserts into the P-P bond of $\mathrm{Cy}_{4} \mathrm{P}_{2}$. The selective synthesis of pentaphospholane $\mathbf{1 3}$ is achieved by the equimolar reaction of 7 with $\mathrm{Cy}_{2} \mathrm{PH}$ in $\mathrm{Et}_{2} \mathrm{O}$ as a non-polar solvent (Scheme 6). The formed precipitate is filtered and

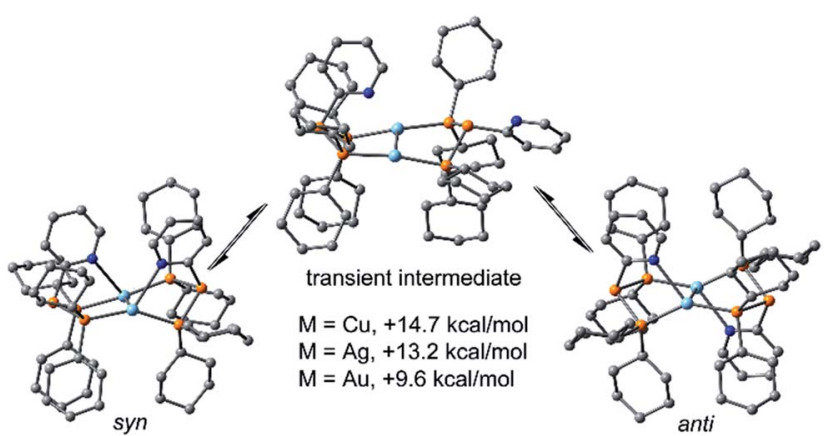

Fig. 6 Interconversion mechanism of the syn- and anti-isomers of $\left[(9 a * M)_{2}\right]^{2+} ;(M=C u, A g$, and $\mathrm{Au})$. 


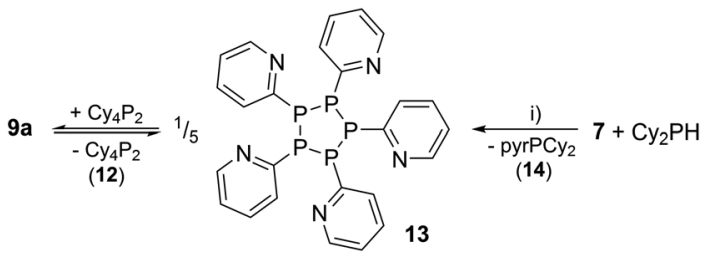

Scheme 6 Equilibrium reaction of 9a with 13 and 12 and selective synthesis of 13 by the reaction of 7 with $\mathrm{Cy}_{2} \mathrm{PH}$; (i) $\mathrm{Et}_{2} \mathrm{O},-\mathrm{pyrH}$.

dried in vacuo giving 13 in 98\% yield as a colourless powder which shows the $\mathrm{AA}^{\prime} \mathrm{BB}^{\prime} \mathrm{C}$ spin system in the ${ }^{31} \mathrm{P}$ NMR spectrum (Fig. 7). Dicyclohexyl(3,5-dimethylpyrazolyl)phosphane (14) is identified as a side product in the supernatant solution by its singlet resonance in the ${ }^{31} \mathrm{P}$ NMR spectrum $(\delta(\mathrm{P})=58.4 \mathrm{ppm})$ indicating a $\mathrm{P}-\mathrm{N} / \mathrm{P}-\mathrm{P}$ bond metathesis reaction. ${ }^{6}$ To further understand the formation of $\mathbf{1 3}$ we studied the reaction in $\mathrm{CD}_{2} \mathrm{Cl}_{2}$ by means of ${ }^{31} \mathrm{P}$ NMR spectroscopy (Fig. 8). After $3.5 \mathrm{~h}$ compound 7 is still present in the solution while $\mathrm{Cy}_{2} \mathrm{PH}$ is fully consumed by the condensation reaction with 7 to form triphosphane 9a (vide supra) and diphosphane $\mathbf{1 5}$ which is identified by an $\mathrm{AX}$ spin system $\left(\delta\left(\mathrm{P}_{\mathrm{A}}\right)=10.2 \mathrm{ppm}\right.$ and $\delta\left(\mathrm{P}_{\mathrm{X}}\right)=$ $\left.33.4 \mathrm{ppm} ;{ }^{1} J\left(\mathrm{P}_{\mathrm{A}} \mathrm{P}_{\mathrm{X}}\right)=-281 \mathrm{~Hz}\right)$. The AMX spin system at $\delta\left(\mathrm{P}_{\mathrm{A}}\right)=$ $-35.6 \mathrm{ppm}, \delta\left(\mathrm{P}_{\mathrm{M}}\right)=-7.2 \mathrm{ppm}$ and $\delta(\mathrm{P})_{\mathrm{X}}=29.9 \mathrm{ppm}$ is assigned to triphosphane $\mathbf{1 6}$ which is formed via a $\mathrm{P}-\mathrm{N} / \mathrm{P}-\mathrm{P}$ bond metathesis reaction of two equivalents of $\mathbf{1 5}$ and via a PN/P-P bond metathesis reaction of 7 and 9a (Scheme 7). In both cases phosphane $\mathbf{1 4}$ is liberated. We propose a further chain growth in which triphosphane $\mathbf{1 6}$ reacts with $\mathbf{1 5}$ with the release of phosphane $\mathbf{1 4}$ in a $\mathrm{P}-\mathrm{N} / \mathrm{P}-\mathrm{P}$ oligomerisation reaction which ultimately yields pentaphospholane 13 . We furthermore propose the formation of tetraphosphetane $17(\delta(\mathrm{P})=-49.4$ $\mathrm{ppm}$ ) which can be formed via the reaction of two equivalents $\mathbf{1 6}$ with concomitant release of $\mathbf{1 4}$ (Scheme 7). Similar to the known ring expansion reactions of certain cyclophosphanes, ${ }^{26}$ 17 might react to form pentaphospholane 13, being the

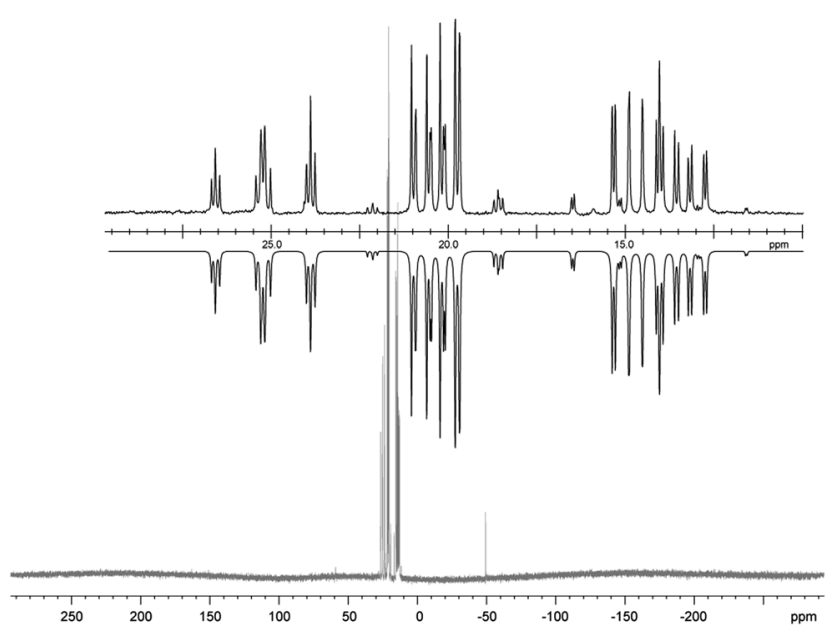

Fig. $7{ }^{31} \mathrm{P}$ NMR spectrum of pentaphospholane $13\left(\mathrm{CD}_{3} \mathrm{CN}, 300 \mathrm{~K}\right.$, the inset shows the $A A^{\prime} B B^{\prime} C$ spin system of the experimental (upwards) and fitted spectra (downwards)).

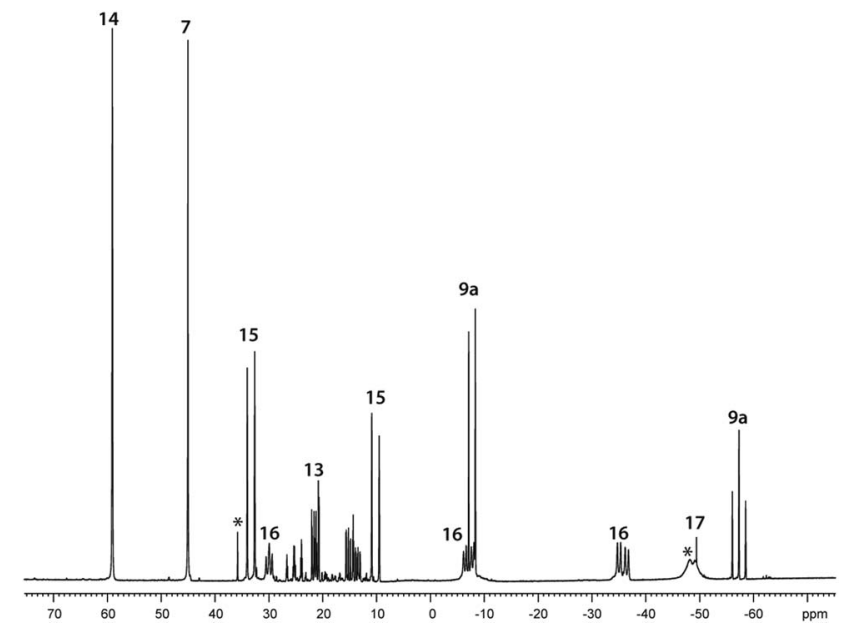

Fig. $8{ }^{31} \mathrm{P}$ NMR spectrum of the reaction of 7 with $\mathrm{Cy}_{2} \mathrm{PH}$ in a $1: 1$ ratio in $\mathrm{CD}_{2} \mathrm{Cl}_{2}$ after $3.5 \mathrm{~h}$; unidentified products are marked with asterisks.

thermodynamically favoured product. In analogy to $\mathbf{1 3}$ we are able to isolate the corresponding benzothiazolyl substituted pentaphospholane 18. ${ }^{27}$ Crystals suitable for X-ray analysis are obtained for both compounds by the slow diffusion of $n$ pentane into saturated $\mathrm{CH}_{2} \mathrm{Cl}_{2}$ solutions at $-30{ }^{\circ} \mathrm{C}$ (Fig. 9).

Both compounds reveal the typical envelope conformation of the $\mathrm{P}_{5}$-ring featuring the substituents in the all-trans position. The P-P bond lengths observed for both pentaphospholanes $\mathbf{1 3}$ (av. P-P $2.218 \AA$ ) and 18 (av. P-P $2.246 \AA$ ) are in a range known for pentaphospholanes such as $(\mathrm{PhP})_{5}$ (av. 2.217 $\mathrm{A}$ ); also the $\mathrm{P}-\mathrm{P}-\mathrm{P}$ angles are in good accordance with the reported data for $(\mathrm{PhP})_{5}{ }^{28}$ We subsequently envisioned the use of $\mathbf{1 3}$ as a PyPsynthon for insertion reactions into P-P bonds which was already indicated by the aforementioned scrambling reaction between 9a, $\mathrm{Cy}_{4} \mathrm{P}_{2}$ and 13 (see Scheme 6).

As similar scrambling reactions might be expected for triphosphanium and triphosphanediium salts, we methylated triphosphane 9a with different amounts of MeOTf. The ${ }^{31} \mathrm{P}$

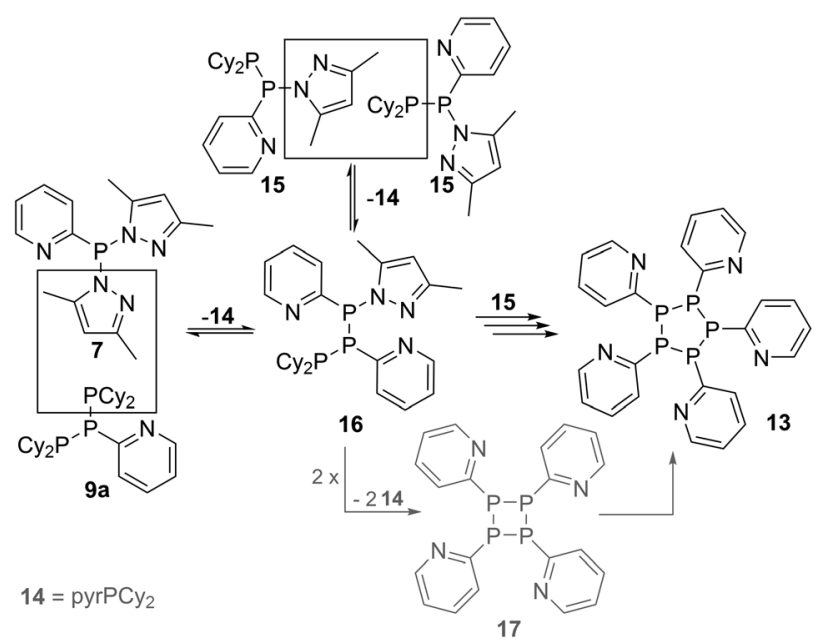

Scheme 7 Possible formation of 16 via P-N/P-P bond metathesis reactions. 


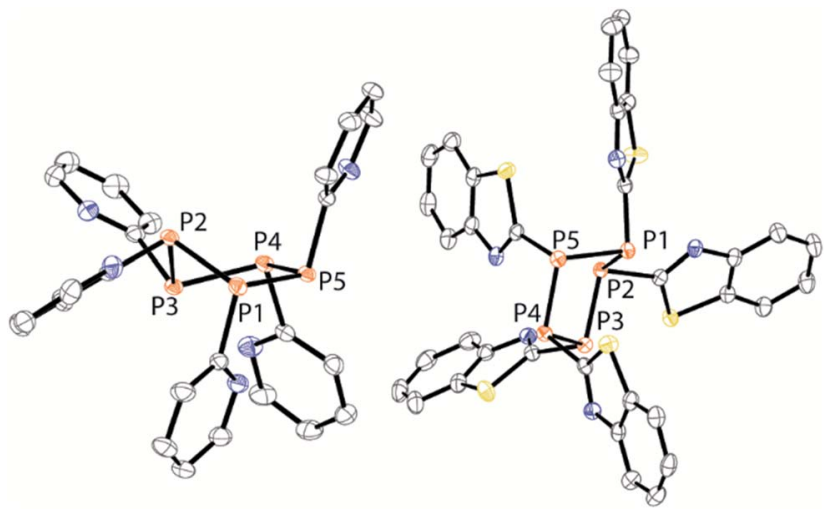

Fig. 9 Molecular structures of the pentaphospholanes 13 (left) and 18 (right) (hydrogen atoms and solvate molecules are omitted for clarity and thermal ellipsoids are displayed at $50 \%$ probability). Selected bond lengths (Å) and angles $\left({ }^{\circ}\right.$ ) (13): P1-P2 2.2222(4), P2-P3 2.2200(5); P3P4 2.22200(5), P4-P5 2.2078(4), P1-P2-P3 97.25(2), P2-P3-P4 95.59(2), P3-P4-P5 102.27(2), P4-P5-P1 106.77(2), P5-P1-P2 97.14(2) (18); P1-P2 2.2336(6), P2-P3 2.2232(6), P3-P4 2.338(6), P4P5 2.2069(6), P5-P1 2.2288(6), P1-P2-P3 93.54(2), P2-P3-P4 100.29(2), P3-P4-P5 107.27(2), P4-P5-P1 96.32(2), P5-P1-P2 96.85(2).

NMR spectrum of the $1: 1$ reaction of 9a with MeOTf shows an AMX spin system $\left(\delta\left(\mathrm{P}_{\mathrm{A}}\right)=-46.2 \mathrm{ppm}, \delta\left(\mathrm{P}_{\mathrm{M}}\right)=-12.9 \mathrm{ppm}\right.$ and $\delta\left(\mathrm{P}_{\mathrm{X}}\right)=34.2 \mathrm{ppm}\left({ }^{1} J\left(\mathrm{P}_{\mathrm{A}} \mathrm{P}_{\mathrm{M}}\right)=-290 \mathrm{~Hz},{ }^{1} J\left(\mathrm{P}_{\mathrm{A}} \mathrm{P}_{\mathrm{X}}\right)=-281 \mathrm{~Hz}\right.$, and $\left.{ }^{2} J\left(\mathrm{P}_{\mathrm{M}} \mathrm{P}_{\mathrm{X}}\right)=58 \mathrm{~Hz}\right)$ ), suggesting the methylation of the phosphorus atom rather than the nitrogen atom of the pyridylsubstituent. After the removal of all volatiles in vacuo triphosphan-1-ium triflate salt 10[OTf] can be isolated in quantitative yield as a colourless powder. A second methylation is achieved when 9a is reacted with an excess of MeOTf under solvent free conditions (Scheme 8). Similar to the aforementioned reaction, only the phosphorus atoms are methylated giving triphosphane-1,3-diiumtriflate salt 11[OTf $]_{2}$. As both dicyclohexylphosphanyl moieties are methylated, the ${ }^{31} \mathrm{P}$ NMR spectrum of $10[\mathrm{OTf}]_{2}$ shows an $\mathrm{AX}_{2}$ spin system with resonances at $\delta\left(\mathrm{P}_{\mathrm{A}}\right)=-67.9 \mathrm{ppm}$ and $\delta\left(\mathrm{P}_{\mathrm{X}}\right)=44.0 \mathrm{ppm}\left({ }^{1} J\left(\mathrm{P}_{\mathrm{A}} \mathrm{P}_{\mathrm{X}}\right)=-315\right.$ $\mathrm{Hz})$. The molecular structures of cation $\mathbf{1 0}^{+}$and dication $\mathbf{1 1}^{2+}$ are depicted in Fig. 10. Note that a small number of triphosphanediium salts are reported in the literature and compound 10[OTf] extends the library of cationic, catenated phosphorus compounds as a structurally characterised triphosphan-1-ium salt. $^{29-31}$ The P1-P2 bond length in cation $\mathbf{1 0}^{+}$(P1-P2 2.1956(5) $\AA$ ) is shortened whereas the P2-P3 bond (P2-P3 2.2362(5) $\AA$ ) is comparable to those in 9a (P1-P2 2.2301(3) $\AA$, P1-P3 2.2371(3) $\AA$ ) or similar diphosphanium cations (compare $\left[\mathrm{Ph}_{2} \mathrm{P}-\mathrm{PPh}_{3}\right]^{+}$:

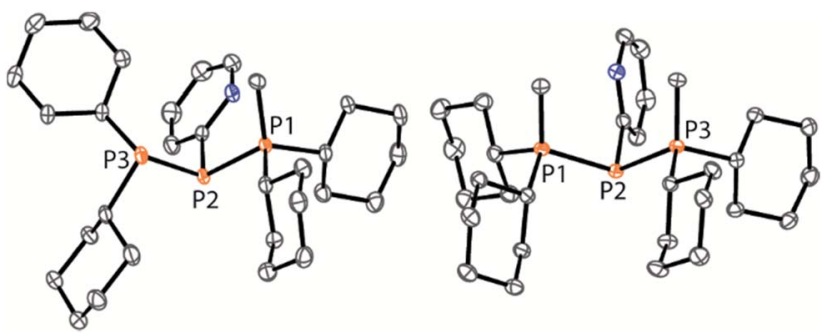

Fig. 10 Molecular structures of $10^{+}$in 10 [OTf] (left) and $11^{2+}$ in 11 $[\mathrm{OTf}]_{2}$ (hydrogen atoms and anions are omitted for clarity and thermal ellipsoids are displayed at $50 \%$ probability). Selected bond lengths $(\AA)$ and angles $\left({ }^{\circ}\right)\left(10^{+}\right)$: P1-P2 2.1956(5), P2-P3 2.2362(5), P1-P2-P3 97.89(2) $\left(11^{2+}\right) ; P 1-P 2$ 2.2152(4), P2-P3 2.2182(4), and P1-P2-P3 107.43(1).

$2.230(1) \AA)^{29 b}$ The P-P-P bond angle in $\mathbf{1 0}^{+}\left(97.89(2)^{\circ}\right)$ is similar to that in compound 9a $\left(97.16(6)^{\circ}\right)$. The $\mathrm{P}-\mathrm{P}$ bond lengths in

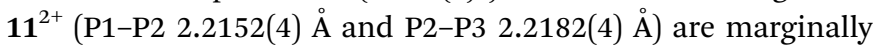
shorter compared to those in 9a but in accordance with bond lengths reported for similar triphosphane-1,3-diium cations (compare $\left[\mathrm{Me}_{3} \mathrm{P}-\mathrm{P}(\mathrm{Cy})-\mathrm{PMe}_{3}\right]^{2+}: 2.1979(5) \AA$ and $\left.2.1976(6) \AA\right) .{ }^{29 b}$ The P-P-P bond angle in $\mathbf{1 1}^{2+}\left(107.43(1)^{\circ}\right)$ is significantly wider compared to those in $9 \mathrm{a}$ and $\left[\mathrm{Me}_{3} \mathrm{P}-\mathrm{P}(\mathrm{Cy})-\mathrm{PMe}_{3}\right]^{2+}\left(103.11(2)^{\circ}\right)$. In order to investigate the envisioned PyP-transfer into a $\mathrm{P}-\mathrm{P}$ bond, we reacted 13 with 5 equivalents of $11[\mathrm{OTf}]_{2}$ in $\mathrm{CH}_{3} \mathrm{CN}$ (Scheme 9). Upon addition of $\mathbf{1 3}$ to a colourless $\mathrm{CH}_{3} \mathrm{CN}$ solution of $\mathbf{1 1}[\mathrm{OTf}]_{2}$ the reaction mixture turns from deep red to pale yellow. The ${ }^{31} \mathrm{P}$ NMR spectrum of the reaction mixture after $24 \mathrm{~h}$ shows two $\mathrm{AA}^{\prime} \mathrm{XX}^{\prime}$ spin systems which are attributed to two isomers of tetraphosphane-1,4-diium cations $19^{2+}$ (Fig. 11), indicating the successful PyP-transfer via a $\mathrm{P}-\mathrm{P} / \mathrm{P}-\mathrm{P}$ bond metathesis reaction. The A part of the prominent $\mathrm{AA}^{\prime} \mathrm{XX}^{\prime}$ spin system at $\delta\left(\mathrm{P}_{\mathrm{A}}\right)=-\mathbf{5 5 . 1} \mathrm{ppm}$ is assigned to the inner pyridylsubstituted $\mathrm{P}$ nuclei and the $\mathrm{X}$ part at $\delta\left(\mathrm{P}_{\mathrm{X}}\right)=40.7 \mathrm{ppm}$ to the tetra-coordinate phosphorus atoms which is similar to known tetraphosphane-1,4-diium salts. ${ }^{32}$ The minor spin system resonates at $\delta\left(\mathrm{P}_{\mathrm{A}}\right)=-40.1 \mathrm{ppm}$ and $\delta\left(\mathrm{P}_{\mathrm{X}}\right)=39.8 \mathrm{ppm}$, respectively. After work-up compound $\mathbf{1 9}[\mathrm{OTf}]_{2}$ can be isolated analytically pure in $51 \%$ yield. X-ray analysis revealed that the centrosymmetric meso-isomer $\mathbf{1 9}^{2+}$ crystallized showing a central torsion angle of $180^{\circ}$ (Fig. 11). The P-P bond lengths in $19^{2+}$ (P1-P2 2.234(1) A and P2-P2'2.232(2) A) are in good agreement with the reported data for comparable tetraphosphane-1,4-diium cations (compare $\left[\mathrm{Ph}_{3} \mathrm{P}-(\mathrm{PPh})_{2}-\mathrm{PPh}_{3}\right]^{2+}: \quad \mathrm{P} 1-\mathrm{P} 2 \quad 2.258(1) \AA$ $2.221(1) \AA) .{ }^{32}$ Similar to the reported PhP-transfer from $(\mathrm{PhP})_{5}$ to a NHC, ${ }^{33} 13$ can be used as a PyP-synthon, thus featuring an

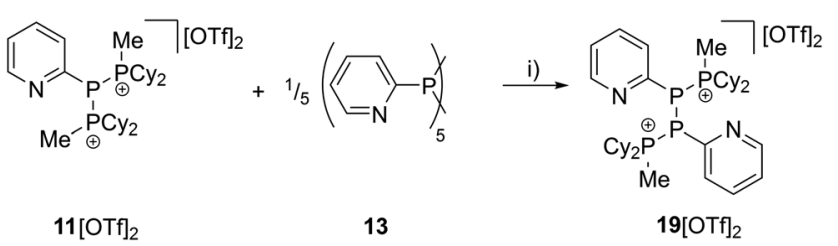

Scheme 9 Synthesis of tetraphosphane-1,4-diium triflate salt 19 $[\mathrm{OTf}]_{2}$; (i) $\mathrm{MeCN}$. 


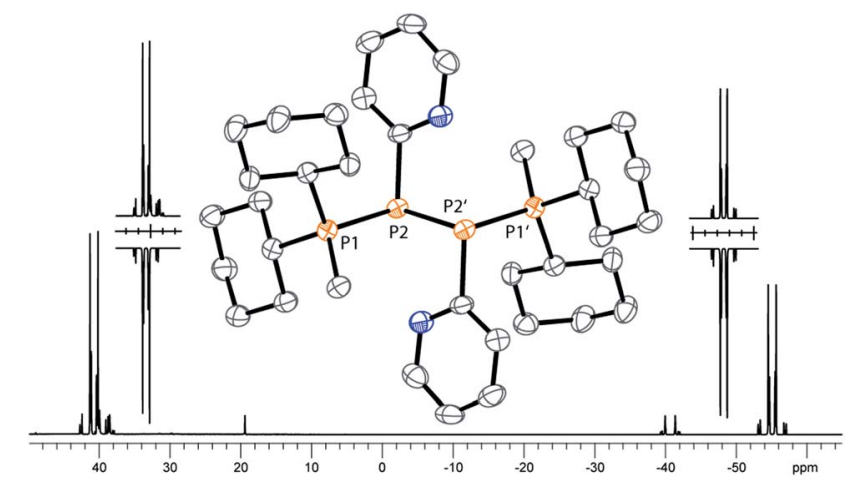

Fig. $11{ }^{31} \mathrm{P}$ NMR spectrum of dication $19[\mathrm{OTf}]_{2}\left(\mathrm{CD}_{2} \mathrm{Cl}_{2}, 300 \mathrm{~K}\right.$, the inset shows the $A A^{\prime} X X^{\prime}$ spin system of the experimental (upwards) and fitted spectra (downwards)); molecular structure of $19^{2+}$ in $19[\mathrm{OTf}]_{2}$ (hydrogen atoms and anions are omitted for clarity; thermal ellipsoids are displayed at $50 \%$ probability). Selected bond lengths $(\AA)$ and angles $\left.{ }^{\circ}\right): P 1-P 2$ 2.234(1), P2-P2' 2.232(2), and P1-P2-P2' 97.60(6).

additional reaction or coordination site. When compound 19 $[\mathrm{OTf}]_{2}$ was kept in a $\mathrm{CD}_{3} \mathrm{CN}$ solution for 14 days, the ${ }^{31} \mathrm{P}$ NMR spectrum shows three rearrangement products (Fig. 12). Next to an $\mathrm{AX}_{2}$ spin system $\left(\delta\left(\mathrm{P}_{\mathrm{A}}\right)=-235.3 \mathrm{ppm}\right.$ and $\delta\left(\mathrm{P}_{\mathrm{X}}\right)=38.8 \mathrm{ppm}$ $\left.\left({ }^{1} J\left(\mathrm{P}_{\mathrm{A}} \mathrm{P}_{\mathrm{X}}\right)=-501 \mathrm{~Hz}\right)\right)$, a pseudo triplet resonance $(\delta(\mathrm{P})=$ $\left.153.1 \mathrm{ppm} ;{ }^{1} J(\mathrm{PN})=50 \mathrm{~Hz}\right)$ and an AMXY spin system $\left(\delta\left(\mathrm{P}_{\mathrm{A}}\right)=\right.$ -208.2 ppm, $\delta\left(\mathrm{P}_{\mathrm{M}}\right)=-30.0 \mathrm{ppm}, \delta\left(\mathrm{P}_{\mathrm{X}}\right)=31.1 \mathrm{ppm}$, and $\delta\left(\mathrm{P}_{\mathrm{Y}}\right)=$ $39.8 \mathrm{ppm} ;{ }^{1} J\left(\mathrm{P}_{\mathrm{A}} \mathrm{P}_{\mathrm{y}}\right)=-490 \mathrm{~Hz},{ }^{1} J\left(\mathrm{P}_{\mathrm{M}} \mathrm{P}_{\mathrm{X}}\right)=-342 \mathrm{~Hz},{ }^{1} J\left(\mathrm{P}_{\mathrm{A}} \mathrm{P}_{\mathrm{M}}\right)=$ $\left.-298 \mathrm{~Hz},{ }^{2} J\left(\mathrm{P}_{\mathrm{M}} \mathrm{P}_{\mathrm{Y}}\right)=91 \mathrm{~Hz},{ }^{2} J\left(\mathrm{P}_{\mathrm{A}} \mathrm{P}_{\mathrm{X}}\right)=45 \mathrm{~Hz},{ }^{3} J\left(\mathrm{P}_{\mathrm{X}} \mathrm{P}_{\mathrm{Y}}\right)=34 \mathrm{~Hz}\right)$ are observed. The $\mathrm{AX}_{2}$ spin system can be attributed to the $3 \lambda^{5}$ triphosph-2-en-1-ium cation $\left(\mathbf{2 0}^{+}\right)$, as the spectroscopic parameters are in the range of those observed for $\left[\mathrm{Ph}_{3} \mathrm{P}-\mathrm{P}-\mathrm{PPh}_{3}\right]^{+}$ $\left(\delta\left(\mathrm{P}_{\mathrm{A}}\right)=-174 \mathrm{ppm}\right.$ and $\left.\delta\left(\mathrm{P}_{\mathrm{X}}\right)=30 \mathrm{ppm} ;{ }^{1} J\left(\mathrm{P}_{\mathrm{A}} \mathrm{P}_{\mathrm{X}}\right)=-500 \mathrm{~Hz}\right)$ which was first reported by Schmidpeter and co-workers. ${ }^{34} \mathrm{~A}$ variety of similar derivatives has been synthesised and reported by the group of Macdonald. ${ }^{35}$ Slow vapour diffusion of $\mathrm{Et}_{2} \mathrm{O}$ into the $\mathrm{CD}_{3} \mathrm{CN}$ solution yielded crystals suitable for X-ray analysis confirming the structural connectivity of $\mathbf{2 0}^{+}$(Fig. 13). The

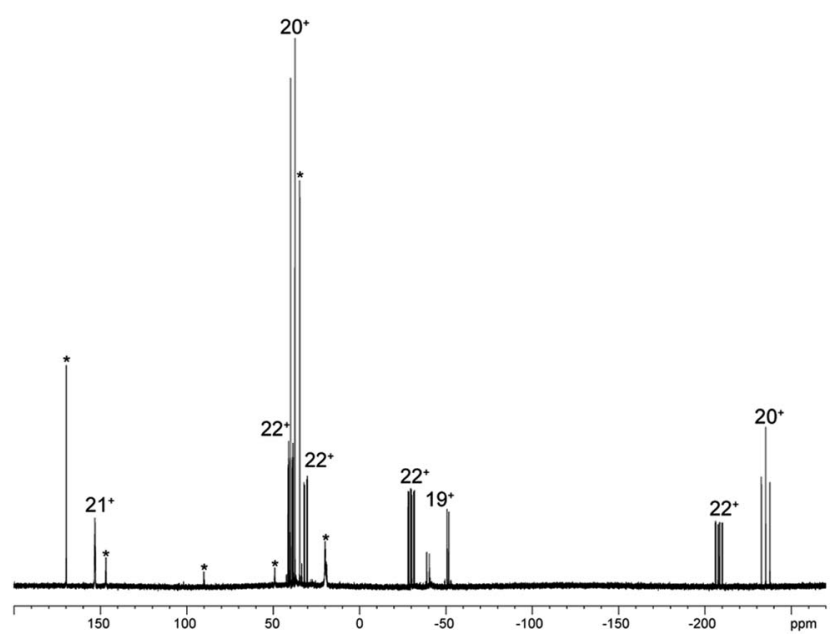

Fig. $12{ }^{31} \mathrm{P}$ NMR spectrum of a solution of $19[\mathrm{OTf}]_{2}$ in $\mathrm{CD}_{3} \mathrm{CN}$ after 14 days.
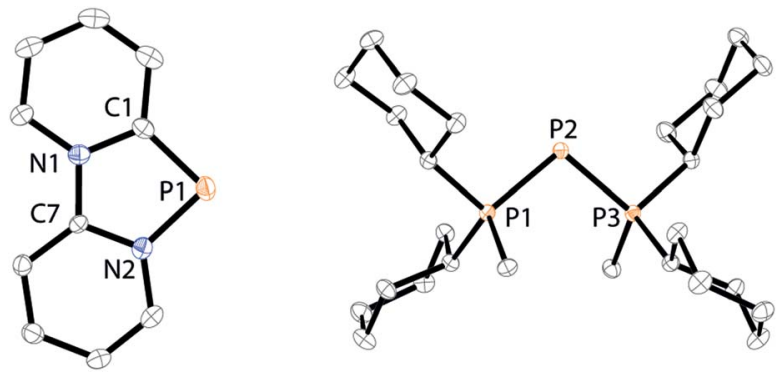

Fig. 13 Molecular structure of 1,4,2-diazaphospholium $21^{+}$in 21[OTf] (left) and $3 \lambda^{5}$-triphosph-2-en-1-ium $20^{+}$in 20[OTf] (right) (hydrogen atoms and anions are omitted for clarity and thermal ellipsoids are displayed at $50 \%$ probability). Selected bond lengths $(\AA)$ and angles $\left({ }^{\circ}\right)$ $\left(20^{+}\right)$: P1-C1 1.733(1), P1-N2 1.741(1), C1-P1-N2 87.08(6) (20); P1-P2 2.134(4), P2-P3 2.1382(4), P1-P2-P3 103.85(2).

structural parameters of $\mathbf{2 0}^{+}$are similar to those observed for the cation $\left[\mathrm{Ph}_{3} \mathrm{P}-\mathrm{P}-\mathrm{PPh}_{3}\right]^{+}$, i.e. slightly shortened $\mathrm{P}-\mathrm{P}$ bond lengths (P1-P2 2.134(4), P2-P3 2.1382(4)) and a P-P-P bond angle of $103.85(2)^{\circ} \cdot{ }^{34}$ By co-crystallisation, a further product was identified as the triflate salt of diazaphospholium cation $\mathbf{2 1}^{+}$(Fig. 13). We assign this species to the pseudo triplet resonance observed in the ${ }^{31} \mathrm{P}$ NMR spectrum. The P-C bond distance of 1.733(1) A slightly exceeds the upper limit of typical $\mathrm{P}=\mathrm{C}$ bond lengths (1.61-1.71 $\AA),{ }^{36}$ while the P-N bond length of P1-N2 1.741(1) $\AA$ indicates a P-N single bond (P-N: $1.78 \AA$ ). ${ }^{37}$ Furthermore, the structure of $\mathrm{21}^{+}$reveals an acute angle around the $\mathrm{P}$ atom (C1-P1-N2 $\left.87.08(6)^{\circ}\right)$ and a planar arrangement, suggesting a delocalized $\pi$ system. We assign the AMXY spin system to asymmetric tetraphosphanediium dication $\mathbf{2 2}^{2+}$, most likely formed by an intramolecular aromatic substitution reaction of $\mathbf{1 9}^{2+}$. This can be attributed to be the first step of the rearrangement reaction of $\mathbf{1 9}^{2+}$ to form $\mathbf{2 0}^{+}$and $\mathbf{2 1}^{+}$. We further studied this rearrangement reaction using the TURBOMOLE 7.0 program at the PB86-D3/ def2-TZVP level of theory (see ESI for details $\dagger$ ) and taking into consideration solvent effects by using the Conductor-like Screening Model (COSMO). Our calculations started from $\mathbf{2 2}^{+}$ and show that the cleavage of $\mathrm{Cy}_{2} \mathrm{PMe}$ is energetically quite costly. This is in accordance with the ${ }^{31} \mathrm{P}$ NMR spectrum as $\mathrm{Cy}_{2} \mathrm{PMe}$ is not observed $(\delta(\mathrm{P})=-19.8 \mathrm{ppm}) .^{38}$ More likely and energetically favoured is a $[1,2]$-shift of the $\mathrm{Cy}_{2} \mathrm{PMe}$ group to form iso-22 ${ }^{2+}$ with a reaction barrier of $+22.0 \mathrm{kcal} \mathrm{mol}^{-1}$. Fig. 14 shows the optimised structures for this $[1,2]-\mathrm{Cy}_{2} \mathrm{PMe}$ shift reaction. It is noteworthy that similar $[1,2]$ - and $[1,3]-\mathrm{PR}_{3}$ shifts have been reported. ${ }^{39}$ Compared to $\mathbf{2 2}^{2+}$, iso-22 ${ }^{2+}$ is almost isoenergetic and

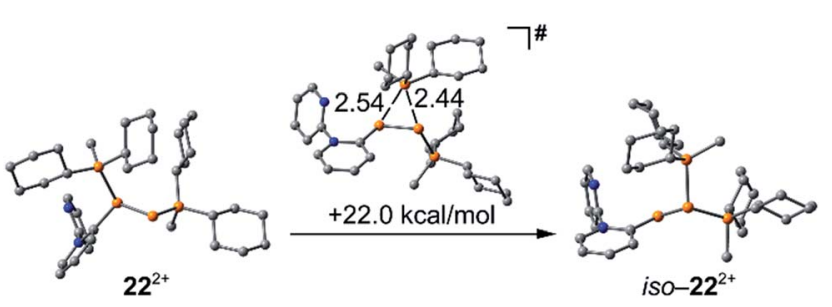

Fig. 14 Optimised structures of $22^{2+}$, iso $-22^{2+}$ and the transition state. 


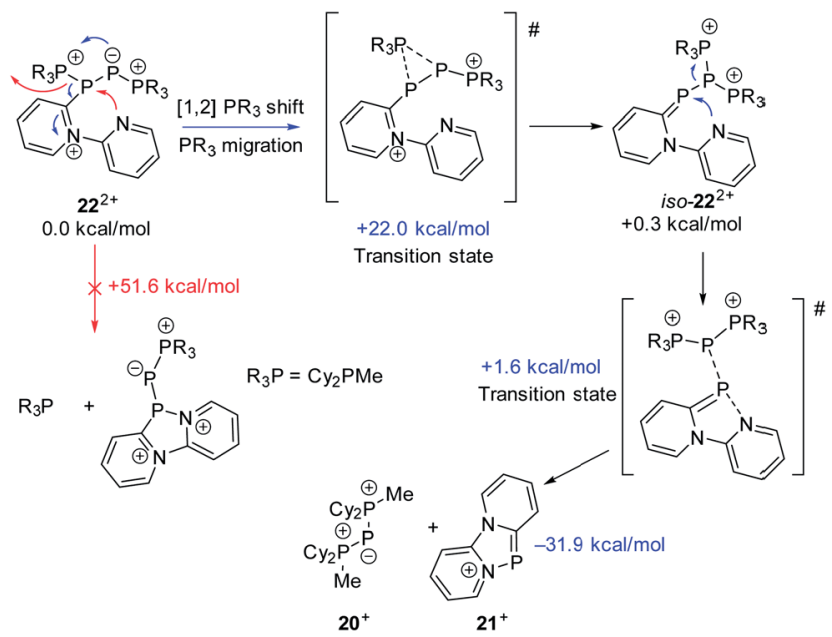

Scheme 10 Rearrangement reaction of $22^{2+}$ to $20^{+}$and $21^{+}$calculated at the PB86-D3/def2-TZVP level of theory.

readily reacts in an exergonic step $\left(-31.9 \mathrm{kcal} \mathrm{mol}^{-1}\right)$ to form cations $\mathbf{2 0}^{+}$and $\mathbf{2 1}^{+}$with a low barrier of only $1.9 \mathrm{kcal} \mathrm{mol}^{-1}$ (see Scheme 10 and ESI for details $\dagger$ ).

\section{Conclusions}

In summary we have shown that phosphanes which we denote as type II phosphanes (two $\mathrm{P}-\mathrm{N}$ bonds and one $\mathrm{P}-\mathrm{C}$ bond) can be used to build polyphosphorus compounds featuring a further nitrogen donor functionality at the $\mathrm{C}$ bound substituent. The reactions of type II phosphanes 7 and 8 with secondary phosphanes of type $\mathrm{R}_{2}^{\prime} \mathrm{PH}$ in a $1: 2$ ratio in $\mathrm{MeCN}$ give triphosphanes 9a-c and triphospholane 9d via protolysis reactions. With the multi-gram scale synthesis of 9a we were able to conveniently investigate its coordination chemistry towards coinage metal salts. The synthesised coordination complexes are studied by X-ray analysis, multi nuclear NMR spectroscopy and quantum chemical calculations. Further reactivity studies of $\mathbf{9 a}$ focused on the reaction with the electrophilic MeOTf. Depending on the amount of MeOTf, the reaction yields triphosphane-1,3-diium triflate salt $11[\mathrm{OTf}]_{2}$ or triphosphan-1-ium 10[OTf] featuring a hitherto unknown structural motif. Pentaphospholanes $\mathbf{1 3}$ and $\mathbf{1 8}$ are synthesised by reacting type II phosphane 7 or 8 with $\mathrm{Cy}_{2} \mathrm{PH}$ in a $1: 1$ ratio in $\mathrm{Et}_{2} \mathrm{O}$ or $\mathrm{CH}_{2} \mathrm{Cl}_{2}$, respectively. The reaction proceeds via a controlled scrambling reaction showing the susceptible solvent dependency of the reaction of 7 and 8 with $\mathrm{Cy}_{2} \mathrm{PH}$. By reacting 11[OTf $]_{2}$ with $\mathbf{1 3}$ we have shown that pentaphospholane $\mathbf{1 3}$ is a suitable PyP-synthon in a P-P/P-P bond metathesis reaction to yield tetraphosphane-1,4-diium triflate $19[\mathrm{OTf}]_{2}$. In an interesting rearrangement reaction $19[\mathrm{OTf}]_{2}$ forms triphosph-2-en-1-ium triflate salt 20 [OTf] and 1,4,2-diazaphospholium triflate 21[OTf] via an unprecedented [1,2]$\mathrm{Cy}_{2} \mathrm{MeP}$ shift. Based on our findings we are certain that controlled $\mathrm{P}-\mathrm{N}(\mathrm{P}) / \mathrm{P}-\mathrm{P}$ bond metathesis reactions will allow us to access larger acyclic and cyclic polyphosphanes in a controlled stepwise manner in order to further investigate their fascinating reaction space.

\section{Conflicts of interest}

There are no conflicts to declare.

\section{Acknowledgements}

We thank the German Science Foundation (DFG Grant number WE 4621/3-1), the European Regional Development Fund, the Free State of Saxony (ERDF-InfraPro, GEPARD-100326379) and the European Research Council (ERC starting grand, SynPhos307616) for financial support. A. F. thanks MINECO/AEI of Spain (project CTQ2017-85821-R FEDER funds) for financial support. A. F. thanks the MINECO of Spain for a "Juan de la Cierva" contract. We also thank Philipp Lange for experimental assistance and EA measurements.

\section{Notes and references}

1 M. Donath, F. Hennersdorf and J. J. Weigand, Chem. Soc. Rev., 2016, 45, 1145; M. H. Holthausen and J. J. Weigand, Chem. Soc. Rev., 2014, 43, 6639; S. Gomez-Ruiz and E. HeyHawkins, Coord. Chem. Rev., 2011, 255, 1360; M. Scheer, G. Balazs and A. Seitz, Chem. Rev., 2010, 110, 4236; M. Baudler, Angew. Chem., Int. Ed. Engl., 1987, 26, 419.

2 (a) M. Baudler, Angew. Chem., Int. Ed. Engl., 1982, 21, 492; M. Baudler and K. Glinka, Chem. Rev., 1993, 93, 1623. ; M. Baudler and K. Glinka, Chem. Rev., 1994, 94, 1273. (b) M. Scheer, St. Gremler, E. Herrmann, U. Grünhagen, M. Dargatz and E. Kleinpeter, Z. Anorg. Allg. Chem., 1991, 600, 203; M. Scheer, St. Gremler, E. Herrmann, M. Dargatz and H.-D. Schädler, Z. Anorg. Allg. Chem., 1992, 619, 1047. (c) G. Fritz, Comments Inorg. Chem., 1982, 6, 329; G. Fritz, Adv. Inorg. Chem., 1987, 171. (d) L. Maier, Helv. Chim. Acta, 1966, 49, 1119; E. Niecke, R. Rüger and B. Krebs, Angew. Chem., Int. Ed. Engl., 1982, 21, 544; A. B. Burg, J. Am. Chem. Soc., 1961, 83, 2226; K. Jurkschat, C. Mugge, A. Tzschach, W. Uhlig and A. Zschunke, Tetrahedron Lett., 1982, 23, 1345.

3 M. Baudler, G. Reuschenbach and J. Hahn, Z. Anorg. Allg. Chem., 1981, 482, 27; G. Fritz and T. Vaahs, Z. Anorg. Allg. Chem., 1987, 553, 85.

4 A. H. Cowley and D. S. Dierdorf, J. Am. Chem. Soc., 1965, 87, 6609; L. R. Avend, R. A. Wolcott, L. V. Cribbs and J. L. Mills, Inorg. Chem., 1989, 28, 200; L. R. Avens, L. V. Cribbs and J. L. Mills, Inorg. Chem., 1989, 28, 211.

5 K.-O. Feldmann, R. Fröhlich and J. J. Weigand, Chem. Commun., 2012, 48, 4296.

6 K.-O. Feldmann and J. J. Weigand, J. Am. Chem. Soc., 2012, 134, 15443.

7 (a) X. Chen, H. Zhu, T. Wang, C. Li, L. Yan, M. Jiang, J. Liu, X. Sun, Z. Jiang and Y. Ding, J. Mol. Catal. A: Chem., 2016, 414, 37; (b) I. V. Komarov, A. V. Strizhak, M. Y. Kornilov, E. Zraudnitskiy and A. A. Tolmachev, Synth. Commun., 2000, 30, 243. 
8 We developed a convenient, salt free synthesis of 5 and 6 which is described in the ESI. $\dagger$

9 (a) S. Fischer, L. K. Peterson and J. F. Nixon, Can. J. Chem., 1974, 52, 3981; (b) S. Fischer, J. Hoyano and L. K. Peterson, Can. J. Chem., 1976, 54, 2710.

$10 \mathrm{H}$. Goldwhite, Introduction to phosphorus chemistry, Cambridge University Press, Cambridge, 1981.

11 R. E. Cobbledick and F. W. B. Einstein, Acta Crystallogr., 1975, B31, 2731.

12 J. J. Daly, J. Chem. Soc. A, 1966, 1020.

13 S. Gomez-Ruiz and E. Hey-Hawkins, Coord. Chem. Rev., 2011, 255, 1360; Phosphorus Chemistry: Catalysis and Material Science Applications, ed. M. Peruzzini and L. Gonsalvi, Springer, vol. 37, 2011.

14 J. W. Dube, C. L. B. Macdonald and P. Ragogna, Angew. Chem., Int. Ed., 2012, 51, 13026; J. W. Dube, C. L. B. Macdonald, B. D. Ellis and R. Paul, Inorg. Chem., 2013, 52, 11438.

15 M. Scheer, C. Kuntz, M. Stubenhofer, M. Zabel and A. Y. Timoshkin, Angew. Chem., Int. Ed., 2010, 49, 188; M. Baacke, S. Morton, G. Johannsen, N. Weferling and O. Stelzer, Chem. Ber., 1980, 113, 1328; W. S. Sheldrick, S. Morton and O. Stelzer, Z. Anorg. Allg. Chem., 1981, 475, 232; M. Scheer, S. Gremler, E. Herrmann and P. G. Jones, J. Organomet. Chem., 1991, 414, 337.

16 D. R. Armstrong, N. Feeder, A. D. Hopkins, M. J. Mays, D. Moncrieff, J. A. Wood, A. D. Woods and D. S. Wright, Chem. Commun., 2000, 2483.

17 C. E. Averre, M. P. Coles, I. R. Crossley and I. J. Day, Dalton Trans., 2012, 41, 278.

18 For a review on argentophilic interactions see: H. Schmidbaur and A. Schier, Angew. Chem., Int. Ed., 2015, 54, 746, for aurophilic interactions see: H. Schmidbaur and A. Schier, Chem. Soc. Rev., 2012, 41, 370.

19 A. Bondi, J. Phys. Chem., 1964, 68, 441.

20 C.-M. Che, Z. Mao, V. M. Miskowski, M.-C. Tse, C.-K. Chan, K.-K. Cheung, D. L. Phillips and K.-H. Leung, Angew. Chem., Int. Ed., 2000, 39, 4084; C.-M. Che, M.-C. Tse, M. C. W. Chan, K.-K. Cheung, D. L. Phillips and K.-H. Leung, J. Am. Chem. Soc., 2000, 122, 2464; C.-M. Che, W.-F. Wu, K.-C. Chan and K.-K. Cheung, Chem.-Eur. J., 2001, 7, 4656.

21 M. Henary, J. L. Wootton, S. I. Khan and J. I. Zink, Inorg. Chem., 1997, 36, 796; P. Aslanidis, P. J. Cox, S. Divanidis and A. C. Tsipis, Inorg. Chem., 2002, 41, 6875.

$22 \mathrm{H}$. Friebolin, Ein- und Zweidimensionale NMR-Spektroskopie, Wiley VCH, Weinheim, 2006; H. Fujii, M. Tomura, T. Kurahashi and M. Kujime, Inorg. Chem., 2007, 46, 541.

$23(a)$ The ${ }^{31} \mathrm{P}$ NMR spectra of $\left[(\mathbf{9 a} \mathrm{Cu})_{2}\right][\mathrm{OTf}]_{2},\left[(\mathbf{9 a} * \mathrm{Ag})_{2}\right][\mathrm{OTf}]_{2}$, $\left[(\mathbf{9 a} * \mathrm{Au})_{2}\right][\mathrm{OTf}]_{2}, \quad\left[(\mathbf{9 a})_{2} * \mathrm{Cu}\right][\mathrm{OTf}]$ and $(\mathbf{9 a} * \mathrm{CuBr})_{2}$ are depicted in the ESI (Fig. 1-5†); (b) Further information on the theoretical calculations on $\left[\left(9 \mathbf{a}^{*} \mathrm{M}\right)_{2}\right][\mathrm{OTf}]_{2}$ is also given in the ESI in chapter $4 . \dagger$

24 K. Schwedtmann, R. Schoemaker, F. Hennersdorf, A. Bauzá, A. Frontera, R. Weiss and J. J. Weigand, Dalton Trans., 2016, 45, 11384.
25 (a) J. P. Albrand, D. Gagnaire and J. B. Robert, J. Am. Chem. Soc., 1973, 95, 6498; (b) J. P. Albrand and J. B. Robert, J. Chem. Soc., Chem. Commun., 1974, 644; (c) L. R. Smith and J. L. Mills, J. Chem. Soc., Chem. Commun., 1974, 20, 808.

26 (a) M. Baudler, J. Hahn and E. Clef, Z. Naturforsch., 1984, 39b, 438; (b) K. Schwedtmann, J. Haberstroh, S. Roediger, A. Bauzá, A. Frontera, F. Hennersdorf and J. J. Weigand, Chem. Sci., 2019, 10, 6868.

27 For further details see the ESI. $\dagger$

28 J. J. Daly, J. Chem. Soc., 1964, 6147.

29 (a) N. Burford, T. S. Cameron and P. J. Ragogna, J. Am. Chem. Soc., 2001, 123, 7947; (b) P. A. Gray, Y.-Y. Carpenter, N. Burford and R. McDonald, Dalton Trans., 2016, 45, 2124. 30 For a review on interpnictogen cations see: A. P. M. Robertson, P. A. Gray and N. Burford, Angew. Chem., Int. Ed., 2014, 53, 6050.

31 For cationic, cyclic polyphosphorus compounds see: J. Bresien, K. Faust, A. Schulz and A. Villinger, Angew. Chem., Int. Ed., 2015, 54, 6926; S. J. Geier, M. A. Dureen, E. Y. Ouyang and D. W. Stephan, Chem.-Eur. J., 2010, 16, 988; Y.-Y. Carpenter, N. Burford, M. D. Lumsden and R. McDonald, Inorg. Chem., 2011, 50, 3342; J. J. Weigand, N. Burford, R. J. Davidson, T. S. Cameron and P. Seeheim, J. Am. Chem. Soc., 2009, 131, 17943; C. A. Dyker, N. Burford, G. Menard, M. D. Lumsden and A. Decken, Inorg. Chem., 2007, 46, 4277; N. Burford, C. A. Dyker, M. Lumsden and A. Decken, Angew. Chem., 2005, 117, 6352. 32 (a) C. A. Dyker, N. Burford, M. D. Lumsden and A. Decken, J. Am. Chem. Soc., 2006, 128, 9632; (b) Y.-Y. Carpenter, C. A. Dyker, N. Burford, M. D. Lumsden and A. Decken, J. Am. Chem. Soc., 2008, 130, 15732.

33 (a) A. J. Arduengo III, H. V. R. Dias and J. C. Calabrese, Chem. Lett., 1997, 143; (b) A. J. Arduengo III, J. C. Calabrese, A. H. Cowley, H. V. R. Dias, J. R. Goerlich, W. J. Marshall and B. Riegel, Inorg. Chem., 1997, 36, 2151; (c) J. H. Barnard, P. A. Brown, K. L. Shuford and C. D. Martin, Angew. Chem., Int. Ed., 2015, 54, 12083.

34 A. Schmidpeter, S. Lochschmidt and W. S. Sheldrick, Angew. Chem., 1985, 97, 214.

35 B. D. Ellis, M. Carlesimo and C. L. B. Macdonald, Chem. Commun., 2003, 1946; B. D. Ellis and C. L. B. Macdonald, Inorg. Chem., 2006, 45, 6864; E. L. Norton, K. L. S. Szekely, J. W. Dube, P. G. Bomben and C. L. B. Macdonald, Inorg. Chem., 2008, 47, 1196.

36 M. Regitz and O. J. Scherer, Multiple Bonds and Low Coordination in Phosphorus Chemistry, Georg Thieme Verlag Thieme Medical Publishers, New York, 1990.

37 H. R. Allcock, Phosphorus-Nitrogen Compounds, Academic Press, New York, 1972.

38 E. Payet, A. Auffrant, X. F. Le Goff and P. Le Floch, J. Organomet. Chem., 2010, 695, 1499.

39 E. Rüba, K. Mereiter, R. Schmid, V. N. Sapunov, K. Kirchner, H. Schottenberger, M. J. Calhorda and L. F. Veiros, Chem.Eur. J., 2002, 8, 3948; C. Coletti, L. Gonsalvi, A. Guerriero, L. Marvelli, M. Peruzzini, G. Reginato and N. Rem, Organometallics, 2010, 29, 5982. 